\title{
Contribution of crenarchaeal autotrophic ammonia oxidizers to the dark primary production in Tyrrhenian deep waters (Central Mediterranean Sea)
}

\author{
Michail M Yakimov ${ }^{1,7}$, Violetta La Cono ${ }^{1,7}$, Francesco Smedile ${ }^{1}$, Thomas H DeLuca ${ }^{2}$, \\ Silvia Juárez ${ }^{3}$, Sergio Ciordia ${ }^{3}$, Marisol Fernández ${ }^{3}$, Juan Pablo Albar ${ }^{3}$, Manuel Ferrer ${ }^{4}$, \\ Peter N Golyshin ${ }^{5}$ and Laura Giuliano ${ }^{1,6}$ \\ ${ }^{1}$ Laboratory of Marine Molecular Microbiology, Institute for Coastal Marine Environment (IAMC), CNR, \\ Messina, Italy; ${ }^{2}$ School of Environment, Natural Resources and Geography, Bangor University, Bangor, \\ Gwynedd, UK; ${ }^{3}$ Proteomic Facility, Centro Nacional de Biotecnología, CSIC, Madrid, Spain; ${ }^{4}$ Laboratory of \\ Enzyme Discovery, Institute of Catalysis, CSIC, Madrid, Spain; ${ }^{5}$ School of Biological Sciences, Bangor University, \\ Bangor, Gwynedd, UK and ${ }^{6}$ Mediterranean Science Commission (CIESM), Monaco
}

\begin{abstract}
Mesophilic Crenarchaeota have recently been thought to be significant contributors to nitrogen (N) and carbon (C) cycling. In this study, we examined the vertical distribution of ammonia-oxidizing Crenarchaeota at offshore site in Southern Tyrrhenian Sea. The median value of the crenachaeal cell to amoA gene ratio was close to one suggesting that virtually all deep-sea Crenarchaeota possess the capacity to oxidize ammonia. Crenarchaea-specific genes, nirK and ureC, for nitrite reductase and urease were identified and their affiliation demonstrated the presence of 'deep-sea' clades distinct from 'shallow' representatives. Measured deep-sea dark $\mathrm{CO}_{2}$ fixation estimates were comparable to the median value of photosynthetic biomass production calculated for this area of Tyrrhenian Sea, pointing to the significance of this process in the $\mathrm{C}$ cycle of aphotic marine ecosystems. To elucidate the pivotal organisms in this process, we targeted known marine crenarchaeal autotrophy-related genes, coding for acetyl-CoA carboxylase (accA) and 4-hydroxybutyryl-CoA dehydratase (4-hbd). As in case of nirK and ureC, these genes are grouped with deepsea sequences being distantly related to those retrieved from the epipelagic zone. To pair the molecular data with specific functional attributes we performed $\left[{ }^{14} \mathrm{C}\right] \mathrm{HCO}_{3}$ incorporation experiments followed by analyses of radiolabeled proteins using shotgun proteomics approach. More than 100 oligopeptides were attributed to $\mathbf{4 0}$ marine crenarchaeal-specific proteins that are involved in 10 different metabolic processes, including autotrophy. Obtained results provided a clear proof of chemolithoautotrophic physiology of bathypelagic crenarchaeota and indicated that this numerically predominant group of microorganisms facilitate a hitherto unrecognized sink for inorganic $\mathrm{C}$ of a global importance.
\end{abstract}

The ISME Journal (2011) 5, 945-961; doi:10.1038/ismej.2010.197; published online 6 January 2011

Subject Category: microbial population and community ecology

Keywords: crenarchaeal accA, amoA, nirk, ureC genes; autotrophic Crenarchaeota; Tyrrhenian Sea; dark ocean primary production; shotgun proteomics

\section{Introduction}

Until recently, autotrophic ammonia oxidation was assumed to be performed exclusively by aerobic and anaerobic ammonia-oxidizing bacteria. Analyzing the Global Ocean Survey (GOS) metagenomic data

Correspondence: MM Yakimov, Department of Marine Molecular Microbiology, Institute for Coastal Marine Environment (IAMC), CNR, Spianata S Raineri 86, Messina 98122, Italy.

E-mail: michail.yakimov@iamc.cnr.it and PN Golyshin, School of Biological Sciences, Bangor University, ECW Building Deiniol Road, Bangor, Gwynedd LL57 2UW, UK.

E-mail: p.golyshin@bangor.ac.uk

${ }^{7}$ These authors contributed equally to this work.

Received 31 May 2010; revised 18 October 2010; accepted 18

November 2010; published online 6 January 2011 obtained from the photic waters of the Sargasso Sea, Venter et al. (2004) identified a putative ammonia monooxygenase (amoA)-like gene in an apparent archaeon-derived scaffold, and thus suggested ammonia $\left(\mathrm{NH}_{3}\right)$ oxidation to be attributed to crenarchaea. More direct indication of archaeal origin of amoA-like genes was obtained by analyzing the soil metagenome, when a similar gene was found on a 43-kb soil DNA fragment harboring the $16 \mathrm{~S}$ rRNA gene of the group 1.1b Crenarchaeota (Treusch et al., 2005). The definitive link between these novel amoA-like genes and archaeal $\mathrm{NH}_{3}$ oxidation was convincingly established recently by cultivation of free-living ammonia-oxidizing crenarchaea (Könneke et al., 2005; Hatzenpichler et al., 2008; de la Torre et al., 2008; Park et al., 2010). 
The 16S rRNA gene phylogeny analysis placed them into the Marine Group 1.1a of Crenarchaeota to become the first cultivated representative of this exceptionally abundant archaeal group. The putative ammonia monooxygenase genes amoA, amoB and amoC organized in one operon were revealed in Nitrosopumilus maritimus SCM1 isolate (Walker et al., 2010). The energy gained from the conversion of $\mathrm{NH}_{3}$ to nitrite allows this crenarchaeon to use bicarbonate chemoautotrophically, as a principal carbon (C) source (Könneke et al., 2005).

As it has been indicated in the review of Erguder et al. (2009), numerous studies have indicated that the archaeal amo $A$ gene is very ubiquitous in the biosphere: it was found in coastal and marine waters, in subterranean estuary, in coastal, estuarine and cold seep sediments, in freshwater sediments, in a subsurface of radioactive thermal spring and neighboring biofilms, in the sediments and microbial mats/mud of hot springs and geothermal biofabrics and in coral reefs. Further, this gene was widely detected in terrestrial systems, including agricultural, forest and grassland soils, in sandy upland soils and saturated rice paddy soils, and in the rhizosphere of the freshwater macrophyte Littorella uniflora. Finally, the amoA gene has been detected in man-made systems, such as aquarium biofilm systems and groundwater filter, and in activated sludge bioreactors (see Erguder et al., 2009 for further references). Remarkably, the majority of studies quantifying archaeal amo $A$ gene abundance in the marine pelagic ecosystems focused on the euphotic and mesopelagic subsystems, in which $\mathrm{NH}_{3}$ is generated by remineralization processes, for example, in the oxygen minimum zone (OMZ) (Francis et al., 2005; Wuchter et al., 2006; Mincer et al., 2007; Beman et al., 2008). However, Crenarchaeota are abundant in bathypelagic (1000-4000-m depth) $\mathrm{NH}_{3}$-depleted waters as well (Karner et al., 2001; Delong et al., 2006; Teira et al., 2006; Martin-Cuadrado et al., 2007; Agogué et al., 2008; Varela et al., 2008) and, despite of their potential importance to the marine nitrogen $(\mathrm{N})$ cycle, there is only limited information available on the distribution and physiological activities of these deep-sea organisms. While studying the archaeal amo $A$ gene distribution in the bathypelagic waters, the question arose whether all deep-sea Crenarchaeota contribute to $\mathrm{NH}_{3}$ oxidation (Mincer et al., 2007; Agogué et al., 2008; De Corte et al., 2009; Church et al., 2010). Studies performed in deep North Atlantic and Eastern Mediterranean Sea revealed that archaeal amoA gene abundance was rather low even though 16S rRNA genes of MGI of Crenarchaeota were abundant, suggesting that Crenarchaeota might largely lack the amo $A$ gene in these deep-water environs (Agogué et al., 2008; De Corte et al., 2009). It was also shown that the general decrease in amo $A$ abundance mirrored the patterns in $\mathrm{C}$ fixation, a phenomenon the authors attributed to a depth-dependent increase in archaeal reliance on chemoorganoheterotrophy rather than autotrophy (Ouverney and Fuhrman, 2000; Pérez et al., 2003; Kirchman et al., 2007). Thus, researchers have postulated the existence of a specific heterotrophic amoA gene-lacking Crenarchaeota, that prefer deep ocean waters (Agogué et al., 2008). However, no clear evidence of depth-dependent changes in the crenarchaeal amoA:16S rRNA gene ratio was found between the near-surface ocean and mesopelagic (down to $1000 \mathrm{~m}$ ) waters of the central Pacific Ocean (Church et al., 2010). Moreover, as we showed earlier (Yakimov et al., 2009), above ratio approaches 1.0 in bathypelagic waters of Central Mediterranean, which contrasts with the data from previous studies (Agogué et al., 2008; De Corte et al., 2009). It is possible that these differences stem, in part, from the selection of quantitative (Q)-PCR primers (Schleper, 2008; Church et al., 2010).

The purpose of the work reported was to closely examine Mediterranean bathypelagic ecosystems for the presence, abundance and ecological significance of autotrophic crenarchael organisms. Specifically, we collected samples from a depth of $3480 \mathrm{~m}$ in the Tyrrhenian Sea (Central Mediterranean) and examined the resident bathypelagic community for abundance of crenarchaeal amo $A$ genes in relation to corresponding transcripts and cell numbers. Further, we analyzed the phylogenetic affiliation of recovered crenarchaeal amo $A$ transcripts and genes putatively encoding for the $\alpha$-subunit of urease, nitrite reductase (NirK), acetyl-CoA carboxylase (AccA) and 4-hydroxybutyryl-CoA dehydratase (4-HBD). To our knowledge, these are the first publicly available gene sequences for deep-sea crenarchaea of Mediterranean Sea. Deep-sea primary production rates were studied in on-deck experiments under the influence of various chemical and physical factors. Finally, in an attempt to definitely link autotrophy with marine Crenarchaeota, we performed the $\left[{ }^{14} \mathrm{C}\right] \mathrm{HCO}_{3}$ incorporation experiments followed by the analyses of radiolabeled proteins using shotgun proteomics approach.

\section{Materials and methods}

Study site and sample collection

Seawater samples were obtained from the Southern Tyrrhenian area of Mediterranean Sea (monitoring station 17 or $\mathrm{V} 2\left(39^{\circ} 32.050^{\prime} \mathrm{N}\right.$ and $\left.13^{\circ} 22.280^{\prime} \mathrm{E}\right)$ ) from onboard the RV Urania during the CIESM-SUB2 (December 2005) and VECTOR-TM2 (February 2007) cruises. Samples from the different depths (200, 400 (OMZ), 2000 and $3480 \mathrm{~m}$ ) were collected using 12-l Niskin bottles housed on a rosette (General Oceanics, Miami, FL, USA) equipped with SBE911plus conductivity-temperature-depth sensors (Sea-Bird Electronics, Bellevue, WA, USA). In addition to the oxygen profile derived from the CTD sensor, parallel determination of oxygen concentration at chosen depths were carried out using the 
Winkler method (Carpenter, 1965) with an automatic endpoint detection burette 716 DNS Titrino (Metrohm AG, Herisau, Switzerland). Samples for determining nutrient concentrations were collected in $20 \mathrm{ml}$ polyethylene vials, quickly frozen in liquid $\mathrm{N}$ and then stored at $-20^{\circ} \mathrm{C}$. Nutrient concentrations were determined within a few weeks of the end of each cruise using SEAL QuAAtro Microflow Analyzer (SEAL Analytical, Hampshir, UK). All running standards were prepared with Low Nutrient Seawater and calibrated against Ocean Scientific standards (OSIL, Hampshir, UK). Sample analyses were performed at least twice using the same set of equipment.

Bacterioplankton sampling and enumeration Hybridization was carried out using $4^{\prime}, 6^{\prime}$-diamidino2-phenylindol (DAPI) staining and catalyzed reporter deposition fluorescence in situ hybridization (CARDFISH). Seawater samples $(1000 \mathrm{ml})$ collected at different depths were directly transferred to glass bottles, fixed with particle-free formaldehyde $(2 \%$ final concentration) and stored at $4{ }^{\circ} \mathrm{C}$ for $12 \mathrm{~h}$. Microbial cells were collected by gentle filtration of $40-120 \mathrm{ml}$ seawater portions onto $0.2-\mu \mathrm{m}$ pore size, $47-\mathrm{mm}$ diameter white polycarbonate filters GTTP (Millipore, Molsheim, France), which were then rinsed with sterile seawater, air-dried and stored at $-20^{\circ} \mathrm{C}$ until further processing as described by Tamburini et al. (2009). Specifically, filters for CARD-FISH counts were embedded in low-gelling point agarose $(0.1 \%$ final concentration, Sigma-Aldrich Chemie $\mathrm{GmbH}$, Steinheim, Germany), dried at $37^{\circ} \mathrm{C}$ for $10 \mathrm{~min}$ and dehydrated with $95 \%$ ethanol. For detection of bacteria, embedded cells were permeabilized by subsequent treatments with lysozyme $\left(10 \mathrm{mg} \mathrm{ml}^{-1}\right.$, Sigma) in $0.5 \mathrm{M}$ EDTA, $0.1 \mathrm{M}$ Tris-HCl $(\mathrm{pH} 8.0)$ for $60 \mathrm{~min}$ at $37^{\circ} \mathrm{C}$ (Amann et al., 1995) and with achromopeptidase (60 U in $0.01 \mathrm{M} \mathrm{NaCl}, 0.01 \mathrm{M}$ Tris-Hcl, $\mathrm{pH}$ 8.0) for $30 \mathrm{~min}$ at $37^{\circ} \mathrm{C}$ according to Sekar et al. (2003). The archaeotal CARD-FISH enumeration was carried out according to the proteinase $\mathrm{K}$ protocol of Teira et al. (2004). Afterwards, the filters were rinsed three times with $0.2-\mu \mathrm{m}$ filtered MilliQ water and placed in $0.01 \mathrm{M} \mathrm{HCl}$ at room temperature to denature endogenous peroxidase. Following acid treatment, filter sections were further hybridized with a solution of $5^{\prime}$-horseradish peroxidase (HRP)labelled oligonucleotide probes (Pernthaler et al., 2002) using a final concentration of $1 \mathrm{ng}^{\mathrm{l}} \mathrm{l}^{-1}$. Probes used in this work are listed in the Supplementary Table S1. After an amplification step with ThyramideAlexa, pieces of filter were mounted on slides, which were examined under an Olympus BX61 microscope equipped with a 100-W Hg-lamp and appropriate filter sets for $4^{\prime}, 6^{\prime}$-diamidino-2-phenylindol and Alexa488. The fraction of CARD-FISH-stained cells in at least $10004^{\prime}, 6^{\prime}$-diamidino-2-phenylindolstained cells per sample was quantified. Negative control counts (hybridization with HRP-Non338;
Karner and Fuhrman, 1997) were always below $5 \%$ ( $1 \%$ average) of $4^{\prime}, 6^{\prime}$-diamidino-2-phenylindolstained cells.

Nucleic acids extraction and cDNA synthesis For nucleic acid extraction, three Niskin bottles were casted at each depth and seawater was immediately filtered onboard with Sterivex capsules $(0.2 \mu \mathrm{m}$ pore size, Millipore), using a peristaltic pump. After filtration, the collected material was resuspended by vortexing for $5 \mathrm{~s}$ in $400 \mu \mathrm{l}$ of TE buffer ( $\mathrm{pH}$ 8.0) containing lysozyme $\left(5 \mathrm{mg} \mathrm{ml}^{-1}\right)$ and incubated $10 \mathrm{~min}$ at room temperature. Lysis was performed by the addition of $1600 \mu$ of lysis buffer QRL1 (Qiagen, Milan, Italy) containing guanidine isothiocyanate and $\beta$-mercaptoethanol and, after vigorous vortexing for $30 \mathrm{~s}$, filters were stored at $-20^{\circ} \mathrm{C}$ until processing in laboratory. Keeping in mind that the short lifetime of mRNA molecules is critical for environmental transcriptomic studies, all operations were performed as fast as possible and with a consistent (60-90 min) time intervals between cast recovery and sample freezing. Nucleic acids extraction was continued in the laboratory and after thawing, the cartridges of the Sterivex filters were opened and the filters and the lysis buffer transferred into 50-ml sterile centrifuge tubes. Total DNA and RNA were further extracted using Qiagen RNA/DNA Mini Kit (Qiagen). The extraction was carried out according to the manufacturer's instructions. Before cDNA synthesis, RNA-containing extracts were purified from DNA by incubation with DNAse I (DNA-free-Kit, Ambion, Austin, TX, USA) at $37^{\circ} \mathrm{C}$ for $30 \mathrm{~min}$ and the RNA concentrations determined using a NanoDrop ND 1000 spectrophotometer (NanoDrop Technologies, Wilmington, DE, USA). Each RNA sample was immediately converted into cDNA with SuperScript II Reverse Transcriptase (Invitrogen, Carlsbad, CA, USA) and random primers as described elsewhere (Yakimov et al., 2007). The reaction was carried out in a MasterCycler 5331 Gradient (Eppendorf, Hamburg, Germany). The cDNA was used as the template for a further PCR amplification. Possible DNA contamination of RNA templates was routinely monitored by PCR amplification of RNA aliquots that were not reverse transcribed. No contaminating DNA was detected in any of these reactions.

PCR-amplification, gene cloning and sequencing Archaeal 16S rRNA, putative archaeal amoA, nirK and ure $C$ and key $\mathrm{C}$ fixation genes $(a c c \mathrm{~A}, 4-b d h$ and $c b b \mathrm{~L})$ of 3-hydroxypropionate/4-hydroxybutyrate and reductive pentose phosphate pathways, respectively, were amplified by PCR using primers listed in the Supplementary Table S2. The PCR reaction was carried out in a MasterCycler 5331 Gradient PCR (Eppendorf). The conditions of the PCR for all the genes were: initial denaturation at $94{ }^{\circ} \mathrm{C}$ for 
$5 \mathrm{~min}$; 35 cycles each of $1 \mathrm{~min}$ at $94{ }^{\circ} \mathrm{C}, 1 \mathrm{~min}$ at $50{ }^{\circ} \mathrm{C}$ and $2 \mathrm{~min}$ at $72{ }^{\circ} \mathrm{C}$; final extension step of $10 \mathrm{~min}$ at $72{ }^{\circ} \mathrm{C}$. PCR products were visualized on an $1 \%$ agarose gel, specific bands were cut out and purified using QIAquick Gel Extraction Kit (Qiagen). Purified PCR products were ligated into pGEM-T-Easy Vector plasmid vector (Promega, Madison, WI, USA) and transformed by electroporation into the E. coli DH10B cells (Invitrogen). Transformants were selected on Luria-Bertani agar containing $100 \mu \mathrm{g} \mathrm{ml}^{-1}$ of ampicillin under blue-white selection. Putativepositive clones of each library were transferred to a 96-well plate that contained Luria-Bertani broth supplemented with ampicillin $\left(100 \mu \mathrm{g} \mathrm{ml}^{-1}\right)$. The clones were grown overnight at $37^{\circ} \mathrm{C}$ and then stored in Luria-Bertani broth with $15 \%$ (v/v) glycerol at $-70{ }^{\circ} \mathrm{C}$ before PCR screening and sequencing. Library clones were screened directly by PCR for the presence of inserts using two M13 universal primers, M13F (5'-GTTTCCCAGTCACGAC-3') and M13R (5'-TCAC ACAGGAAACAGCTATGAC-3'). The conditions for PCR screening were same as described above. Positive clones from each library were randomly selected and after PCR amplification, the DyeEx 96 Kit (Qiagen) was used for removal of unincorporated dye terminators. The purified products were further sequenced at Macrogen (Seoul, South Korea).

\section{Phylogenetic analysis}

We checked all sequences to remove chimeric sequences using the Chimera check program at Ribosomal Database Project (Cole et al., 2005) and Basic Local Alignment Search Tool (BLAST) analysis of sequence segments (Altschul et al., 1997). Phylogenetic analysis was performed as previously described (Yakimov et al., 2007, 2009). Briefly, all sequences were edited and aligned with MacVector Software version 11.0.2 (Accelrys, San Diego, CA, USA) (Rajagopal, 2000). On the basis of distance matrix, clones having $97 \%$ sequence similarity or higher were treated as the same phylotype (Schloss and Handelsman, 2005). The sequences of phylotypes were realigned with other published sequences, including the closest one determined by BLAST. Phylogenetic trees were constructed using the Neighbour-Joining method and Jukes-Cantor distance matrix; 1000 bootstrap re-samplings were performed to estimate the reproducibility of the tree. Random order input of sequences, single jumbling and the global rearrangement option were used. A multiple sequence alignment and the phylogeny of protein homologs were constructed using MacVector 11.0.2 software with BLOSUM matrix and open and extend gap penalties of 10.0 and 0.05 , respectively. The alignment file was then analyzed with the same software for calculation of the distance matrix. Neighbor-Joining algorithm and Poisson correction of distances were used to construct the phylogenetic tree; 1000 bootstrap replicates were performed to estimate the reproducibility of the tree.
Quantification of amoA transcripts and gene copies Q-PCR analysis of environmental DNA templates was performed and the abundance of crenarchaeal amoA-like was evaluated by TaqMan gene expression assay. The reaction was performed in an ABI 7500 Fast Real-Time PCR System thermocycler. The primers and the TaqMan probe used are listed in Supplementary Table S2. 5'-6-FAM and 3'-TAMRAlabeled TaqMan probe was obtained from PE Applied Biosystems (Carlsbad, CA, USA). The experiment was performed using DNA templates originating from all depths sampled in triplicates along with a 'no template control'. Mixtures for Q-PCRs and the reaction conditions were as previously described (Yakimov et al., 2007). Q-PCR amplification was analyzed using an automatic setting of the baseline and threshold values. The standard curve method was applied to generate the absolute quantification of amo $A$ gene copies using a serial dilution ranging from $10^{7}$ to 10 copies of plasmid containing amoA gene (626-bp long fragment). The plasmid was the pGEM T-Easy Vector II harboring the crenarchaeal amoA-like gene (AM747269), extracted using PureLink HiPure Plasmid (Invitrogen S.R.L., San Giuliano Milanese, Italy) and quantified using a Nanodrop ND-1000 spectrophotometer (Wilmington, DE, USA).

\section{Measurements of $\mathrm{CO}_{2}$ fixation}

Rates of $\mathrm{CO}_{2}$ fixation were determined by the incorporation of $\mathrm{NaH}^{14} \mathrm{CO}_{3}$ into particulate organic matter during radiotracing of water samples incubated at the in situ temperature $\left(13^{\circ} \mathrm{C}\right)$ immediately after cast retrieval on board of the research vessel. Three replicate gas-tight $60-\mathrm{ml}$ serum vials were filled with $40 \mathrm{ml}$ of $1 \mu \mathrm{m}$-prefiltered seawater collected at 200, 400 (OMZ), 2000 and $3480 \mathrm{~m}$ and $10 \mu \mathrm{Ci}$ of $\left[{ }^{14} \mathrm{C}\right] \mathrm{HCO}_{3}\left(52 \mathrm{mCi} \mathrm{mM}^{-1}\right.$, Amersham Italia, Milan, Italy) was added to each tube. The experiments included the following controls: experiment in the dark without any amendments and one fixed blank (addition of formaldehyde ( $2 \%$ final concentration) before the experiment) supplemented with $\left[{ }^{14} \mathrm{C}\right] \mathrm{HCO}_{3}$ (final concentration $0.25 \mu \mathrm{Ci} \mathrm{ml}^{-1}$ ). The effect of different additives and antibiotics was evaluated in combination with the $\left[{ }^{14} \mathrm{C}\right] \mathrm{HCO}_{3}$ incorporation. The additives tested were as follows: ammonium chloride $\left(5.0,50 \mu \mathrm{mol} \mathrm{l}^{-1}\right.$ and $0.6 \mathrm{mmol} \mathrm{l}^{-1}$, final concentration), nitrite $\left(1 \mathrm{mmol}^{-1}\right.$, final concentration), nitrate ( $1 \mathrm{mmol}^{-1}$, final concentration), allylthiourea $\left(86 \mu \mathrm{mol} \mathrm{l}^{-1}\right.$, final concentration), azide ( $25 \mu \mathrm{mol} \mathrm{l}{ }^{-1}$, final concentration), cysteine $\left(1 \mathrm{mmol}^{-1}\right.$ final concentration) and urea $\left(500 \mu \mathrm{mol}^{-1}\right.$, final concentration); the antibiotics tested were rifampicin $\left(100 \mu \mathrm{g} \mathrm{ml}^{-1}\right)$, radicicol $\left(20 \mu \mathrm{g} \mathrm{ml}^{-1}\right)$ and streptomycin $\left(25 \mu \mathrm{g} \mathrm{ml}^{-1}\right)$. Additionally, the effect of light was also evaluated by exposition of the samples to led daylight lamp of 12000 lux, corresponding to daylight intensity. Each experiment was performed in triplicate for 7 days and, at the end of this period 
of incubations, was stopped by the addition of formaldehyde ( $2 \%$ final concentration). Before filtration, all samples were alkalified by the addition of $50 \mu \mathrm{l}$ of $10 \mathrm{~mol} \mathrm{NaOH}$ and filtered through $0.1 \mu \mathrm{m}$ polycarbonate filters (Millipore). Filters were washed three times with $10 \mathrm{ml}$ of filtered $(0.1 \mu \mathrm{m})$ seawater, acidified in an HCl fume hood for $12 \mathrm{~h}$ (to remove inorganic carbon) and air-dried before addition of scintillation cocktail for ${ }^{14} \mathrm{C}$ counting in a Wallac 1414 analyzer (PerkinElmer, Monza, Italy). The dpm values were corrected by subtracting the values detected in the controls from the absolute dpm obtained in the samples. Remarkably, the dpm values obtained in non-treated controls (radioactivity background) were comparable with those of formaldehyde-fixed, thus, unambiguously indicating the absence of any abiotic binding of ${ }^{14} \mathrm{C}$-labeled bicarbonate. The ratio of ${ }^{14} \mathrm{C}$-labelled bicarbonate to total inorganic $\mathrm{C}$ in the sample was determined using an average concentration of total $\mathrm{TCO}_{2}$ of $2.29 \pm 0.01 \mathrm{mM}$, measured in seawater column in the Southern Tyrrhenian Sea at the time of sampling (Rivaro et al., 2010). Following the equation that $10 \mu \mathrm{Ci}$ of $\left[{ }^{14} \mathrm{C}^{2} \mathrm{HCO}_{3} \quad\left(52 \mathrm{mCi} \mathrm{mmol}{ }^{-1}\right.\right.$, Amersham Italia) added to the sample corresponds to $2.31 \mu \mathrm{g}^{14} \mathrm{C}$, one incorporated dpm means $177 \mathrm{pgCl}^{-1}$ per day and according to Herndl et al. (2005) was used for estimation of $\mathrm{C}$ uptake rates or values of dark ocean primary production. Differences in dark primary production rates measured in treated and untreated samples were analyzed with unpaired two-tailed Student's $t$-tests or one-way analysis of variance followed by Tukey's multiple comparison test with GraphPad Prism software (San Diego, CA, USA). Data were expressed as mean \pm s.d. derived from at least three independent experiments. Differences were considered significant at $P<0.05$.

$\left[{ }^{14} \mathrm{C}\right] \mathrm{HCO}_{3}$ incorporation analysis by shotgun metaproteomics using reverse phase-high-performance liquid chromatography followed by tandem mass spectrometry (MALDI-TOF/TOF) for peptide sequencing and protein identification

In order to determine the eventual assimilation of labeled inorganic $\mathrm{C}$ into biomarkers and identify the organisms important in deep-sea primary production, $200 \mu \mathrm{Ci}$ of $\left[{ }^{14} \mathrm{C}\right] \mathrm{HCO}_{3}$ was added to $200 \mathrm{ml}$ of $1 \mu \mathrm{m}$-prefiltered seawater collected from the depth of $3480 \mathrm{~m}$ and incubated in the gas-tight $500 \mathrm{ml}$ flask at in situ water temperature $\left(13^{\circ} \mathrm{C}\right)$ in the dark for 7 days. A control culture was incubated under the same conditions without addition of ${ }^{14} \mathrm{C}$-labeled bicarbonate. Total cells were harvested by filtration onto $0.22 \mu \mathrm{m}$ pore size, $47-\mathrm{mm}$ diameter white polycarbonate filters GTTP (Millipore). Filters were cut in pieces, dipped in $2 \mathrm{ml}$ BugBuster protein extraction reagent (Novagen Srl, Podenzano, Italy) and put on ice for $30 \mathrm{~min}$ with gentle agitation ( 100 r.p.m.) in an orbital shaker. After incubation, the samples were sonicated for a total of $1.2 \mathrm{~min}$ and further spun at $15000 \mathrm{~g}$ for $15 \mathrm{~min}$ and the supernatant retained. The protein mixture was then freeze-dried and stored at $-86^{\circ} \mathrm{C}$ until use. Total protein samples were solubilized in $1 \mathrm{ml}$ solvent A (1 $\mathrm{ml}$ of trifluoroacetic acid in $1000 \mathrm{ml}$ of water) and ${ }^{14} \mathrm{C}$-labeled proteins were separated from the starting and non-labeled material by high-performance liquid chromatography using a ultraviolet detection system coupled with a flow-scintillation counter. The Vydac 218TP54 column (C18, $5 \mu \mathrm{m}, 4.6 \mathrm{~mm}$ i.d. $\times 250 \mathrm{~mm}$ ) was equilibrated with $70 \%$ solvent $\mathrm{A}$ ( $1 \mathrm{ml}$ of trifluoroacetic acid in $1000 \mathrm{ml}$ of water) and $30 \%$ solvent B $(700 \mathrm{ml}$ of acetonitrile, $300 \mathrm{ml}$ of water and $1 \mathrm{ml}$ of trifluoroacetic acid) to give a final concentration of $21 \%$ acetonitrile. A flow rate of $1.5 \mathrm{ml} \mathrm{min}{ }^{-1}$ with 100 min linear gradient was used to achieve $70 \%$ of buffer B (49\% acetonitrile). The protein mixture was injected onto the column and the fraction collector was programmed to collect 0.1 -min fractions. Finally, the ${ }^{14} \mathrm{C}$-labelled protein fractions were pooled together and evaporated to dryness in a vacuum concentrator (Model 5301, Eppendorf AG). The pool of labeled proteins obtained using this protocol was further used for shotgun proteomic analysis: complete details describing trypsin digestion of ${ }^{14} \mathrm{C}$-labeled proteins and following RP-LC-MALDI TOF/TOF MS analysis of obtained peptide are found in SI Materials and methods section. Raw shotgun-MS files containing a peak list of the precursors and fragment ions were filtered and exported with the Peak to Mascot tool (4000 Series Explorer Software, ABI). The filtered files were submitted for database search using MASCOT search engine version 2.3.01 (Matrix Science, London, UK). The search was performed in NCBI non-redundant 20100903 database (11 744690 sequences). The following search parameters were used: enzyme, trypsin; allowed missed cleavages, 1; fixed modifications, $\beta$-methylthiolation of cysteine; variable modifications, oxidation of methionine and acetylation (N-term); mass tolerance for precursors was set to \pm 100 p.p.m. and for MS/MS fragment ions to $\pm 0.8 \mathrm{Da}$. The confidence interval for protein identification was set to $\geqslant 95 \%(P<0.05)$ and only peptides with an individual ion score above the identity threshold were considered correctly identified.

\section{Analysis of marine metagenomic data sets}

Sequences of $N$. maritimus SCM1 and C. symbiosum A genes were queried against the NCBI nonredundant protein database using both BLASTP and BLASTX search with a cut-off value of $<1 \mathrm{e}-50$. Only top BLAST high-scoring pairs derived from marine metagenomic libraries were considered for further analyses and tabulated according to the NCBI taxonomic identifier for each query. For comparative analysis, reciprocal BLASTN and TBLASTX searches between the different fosmids, scaffolds and genomic fragments were carried out, leading to the identification of regions of similarity, 
insertions and rearrangements. To allow the interactive visualization of genomic fragment comparisons, MacVector (version 11.0.2) was used.

\section{Nucleotide accession numbers}

The nucleotide sequences reported in this paper have been deposited in the DDBJ/EMBL/GenBank databases under accession numbers: HM241829 to HM241835 for the archaeal 16S rRNA gene sequences, HM355483 to HM355500 for the crenarchael accA gene sequences, HM355502 to HM355518 for the crenarchael nirK gene sequences, HM355519 to HM355532 for the crenarchael ureC gene sequences, HM355501 for the bacterial cbbL gene sequence, HM369442 to HM369457 for the crenarchaeal amoA gene sequences and HQ339937 to HQ339951 for crenarchaeal 4hbd gene sequences.

\section{Results and discussion}

Description of the Tyrrhenian Deep Water (TDW) archaeal community composition

The Tyrrhenia Sea is a three-layer system in which the top layer $(0-200 \mathrm{~m})$ is occupied by the so-called Modified Atlantic Water $(0-250 \mathrm{~m})$, originated from the water entering at Gibraltar from the Atlantic Ocean. The intermediate layer $(250-700 \mathrm{~m})$ is dominated by the Levantine Intermediate Water, whereas the deeper compartments are occupied by TDW formed by the mixing of highly oligotrophic Levantine Intermediate Water with dense waters resident in the Western basin (Millot et al., 2006; Ribera d'Alcalà et al., 2009). At the monitoring Station 17 we mapped nutrient concentration on four depth horizons: 200, $400 \mathrm{~m}$ (corresponding to a somewhat pronounced OMZ with an oxygen concentration of $191 \pm 4 \mu \mathrm{mol} \mathrm{l}^{-1}$ ), 2000 and $3480 \mathrm{~m}$. The deeper layers, encompassing the TDW, are characterized by minimal differences in salinity (0.01 unit), temperature $\left(0.08^{\circ} \mathrm{C}\right)$, oxygen $(13 \mu \mathrm{mol})$ and nutrient $(0.3-0.5 \mu \mathrm{mol})$ concentration. Temperature at the $3480 \mathrm{~m}$ depth at the time of sampling was $14.09{ }^{\circ} \mathrm{C}$, salinity 38.48 practical salinity units (PSU) and oxygen concentration $233 \pm 4 \mu \mathrm{mol} \mathrm{dm}{ }^{-3}$. Nutrients concentrations exhibited the common depth-increasing trend reaching at the depth of $3480 \mathrm{~m}$ the concentration of total inorganic $\mathrm{N}$, phosphates and silicates were $7.94 \pm 0.45,0.31 \pm 0.03$ and $9.32 \pm 0.51 \mu \mathrm{mol} \mathrm{l}^{-1}$, respectively. Dominant patterns for total inorganic N observed in all layers demonstrated an absolute dominance of $\mathrm{NO}_{3}^{-}$at the expenses of $\mathrm{NO}_{2}^{-}$and $\mathrm{NH}_{4}^{+}$, which is typical feature for highly oligotrophic TDW (Ribera d'Alcalà et al., 2009).

According to results of archaeal 16S rRNA clone library analysis (88 clones sequenced in total), the bathypelagic zone of Station 17 was significantly enriched by Crenarchaeota belonging to four distinct subclusters within Marine Group I.1a (95.4\% of all clones sequenced). Equally presented members of Crenarchaeota pSL12-like Clade and

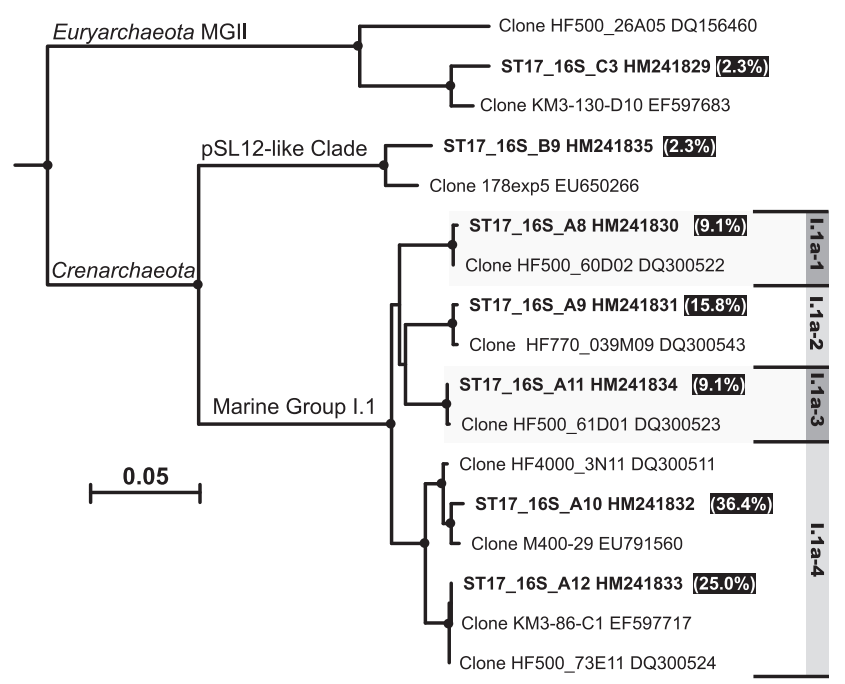

Figure 1 Phylogenetic tree of the archaeal 16S rRNA gene sequences retrieved from deep Tyrrhenian Sea $(3480 \mathrm{~m})$. The tree was constructed by Neighbour-Joining method and Jukes-Cantor distance matrix using MacVector 11.0.2 and a total of 550 nonambiguously aligned positions. Non-parametric bootstrapping was performed upon 1000 iterations. Bootstrap values $>70$ are shown with filled circles. The tree was rooted with Alcanivorax borkumensis strain SK2 16S ribosomal RNA gene (Y12579). The frequencies of all archaeal (sub)groups present in ST17 clone library are evidenced at the end of each sequence. The scale bar represents the number of fixed mutations per nucleotide position.

euryarchaeal Marine Group II encountered for remaining clones (Figure 1). The observed differences between eury- and crenarchaeotal presence in deep Tyrrhenian Sea might be a common phenomenon and is consistent with the findings of other studies (DeLong et al., 2006; Martin-Cuadrado et al., 2007, 2008; Mincer et al., 2007; De Corte et al., 2009; Yakimov et al., 2009).

AmoA mRNA and gene-based diversity analyses and real-time PCR quantification

The abundance of Crenarchaeota MGI.1a in the deep Tyrrhenian Sea corroborated with significant abundance of crenarchaeal $a m o A$ gene as revealed by QPCR: the number of $a m o A$ gene copies found at the depth of $3480 \mathrm{~m}$ in Tyrrhenian Sea $(7000 \pm 475$ copies per $\mathrm{ml}$ ) was essentially the same as the number of crenarchaeal cells (5950 \pm 360 cells ml $^{-1}$ ) counted at this site with CARD-FISH, resulting in amo $A$ to crenarchaeal cells ratio of 1.18. A similar ratio (1.31) was obtained previously at another deepsea site in Tyrrhenian Sea (monitoring Station 4, $\left(39^{\circ} 32.050^{\prime} \mathrm{N}, 13^{\circ} 22.280^{\prime} \mathrm{E}\right)$ ) (Yakimov et al., 2009). Estimates of amoA to total crenarchaeal 16S rRNA gene ratio (median value 1.3) observed in deep-sea environments in other parts of the world, did not vary significantly and have been used to indicate that the marine crenarchaea all possess the ability to perform nitrification (Wuchter et al., 2006; Mincer et al., 2007; Beman et al., 2008; Church et al., 2010; Park et al., 2010). In contrast, Agogué et al. (2008) 
and De Corte et al. (2009) found ratios of archaeal amoA/16S rRNA gene copy number were never exceeded $0.05(0.01 \pm 0.02, n=5)$ in the bathypelagic waters of the Mediterranean Sea and Atlantic ocean, suggesting that a large part of the deep water crenarchaea do not have the ability to perform nitrification. It should be noted, however, that a recent metagenomic study of deep sea microbial communities indicated that the reported low archaeal amoA/16S rRNA gene copy number for deep sea crenarchaea may be erroneous due to mismatches in the primers (Konstantinidis et al., 2009; Church et al., 2010). Aligning these primers with all available deep Mediterranean amoA genes sequences (Yakimov et al., 2007, 2009), we have found up to six mismatching nucleotides (Supplementary Figure S1).

On the basis of the RT-QPCR analysis of amoA mRNA transcripts, we examined the expression of this gene in bathypelagic waters of Tyrrhenian Sea. At the depth of $3480 \mathrm{~m}$ the amoA transcript abundances $(13.2 \pm 0.06$ copies per $\mathrm{ml})$ were approximately 500 times lower than the gene numbers resulting in ratio of $1.86 \times 10^{-3}$. Similar values were observed in the mesopelagic waters of the Pacific Ocean (Church et al., 2010), reflecting similarity in corresponding metabolic activity of crenarchaeal deep-sea communities worldwide. Besides RT-QPCR-based expression analysis of amoA transcripts, corresponding cDNA was used for clone library construction followed by sequencing of 96 clones and phylogenetic analysis. Almost three quarters of sequenced transcripts belonged to Shallow Marine amoA Clade (amoA SMC), a large cluster of sequences from shallow waters, marine sediments, corals, sponges and aquariums (Francis et al., 2005; Mincer et al., 2007; Beman et al., 2008).

Figure 2 Phylogenetic relationships of crenarchaeal amoA-like sequences retrieved from deep Mediterranean Sea: (a) Stations 4 (DMTS_3000m (Yakimov et al., 2009) and 17 (DMTS_3500 m) in Tyrrhenian Sea and Stations KM3 (DTIS_3000 m) and l'Atalante (DMIS_3400 m) in Ionian Sea. The abbreviations DMTS and DMIS stand for Deep Mediterranean Tyrrhenian and Ionian Sea, respectively. All Mediterranean Sea amoA clones are shown in bold. The clones obtained by RT-PCR of amoA derived from mRNA have the letter $\mathrm{R}$ at the end of the legend and black-shaded. The tree was constructed using sequences of comparable regions of the amoA gene sequences available in public databases. The tree is rooted and out-grouped with amo $A$ genes of terrestrial origin (DQ148872 and AJ627422). Neighbor-Joining analysis using 1000 bootstrap replicates was used to infer tree topology and the nodes with the percentage of bootstrap re-sampling above $75 \%$ is indicated by filled cycles. The scale bar represents $5 \%$ sequence divergence. Abbreviation used: ALOHA, North Pacific Subtropical Gyre ALOHA station; ChS, China Sea; ETNPOMZ, Eastern Tropical North Pacific Oxygen Minimum Zone; GOC, Gulf of California; GOM, Gulf of Mexico; HTV, hydrothermal vent; MB, Monterey Bay; OMZ, Oxygen Minimum Zone; SOT, Southern Okinawa Trough. (b) Relative attribution (in percentage) of deep Mediterranean crenarchaeal amo $A$ gene and gene transcripts to Marine Water Column Clades A an B. Four subgroup (B.1-B.4) are defined within Marine Water Column B or Deep Marine amoA Clade as it is shown in phylogenetic tree.
None of amoA SMC gene sequences were observed in DNA-derived library in which sequences formed four separated subgroups ( $>98 \%$ similarity) within Water column B/Deep Marine amoA Clade (amoA DMC). Only two subgroups, namely B.2 (16\% of clones) and B.4 (7\%), were represented in the $a m o A$ transcripts library (Figure 2). Thus, as previously observed (Yakimov et al., 2009), the sampled TDW
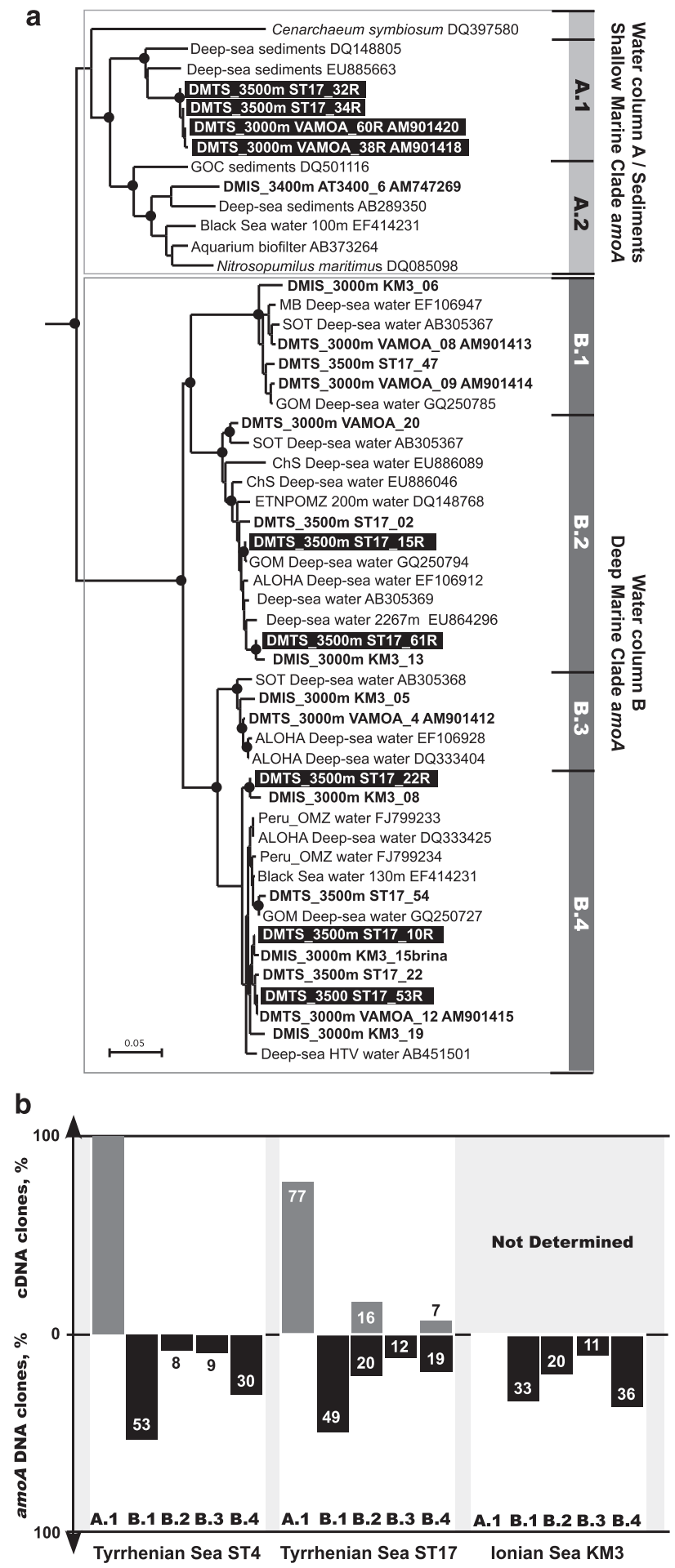
possessed remarkable differences between crenarchaeal amoA transcript and gene pools, that is, mRNA-based libraries were significantly enriched by SMC-like sequences, which were not found in DNA-derived libraries. To date, there is only limited information available on factors regulating transcription of amoA in of ammonia-oxidizing Crenarchaeota in the deep sea. A recent study found that numbers of crenarchaeal amo $A$ gene copies normalized vs their transcripts were greatest in the epipelagic waters of South Pacific and decreased several orders of magnitude with depth (Church et al., 2010). This finding was attributed to the reduced concentration of $\mathrm{NH}_{4}^{+}$in meso- and bathypelagic zones (Mincer et al., 2007). The sampling biases, such as duration of deep-sea sampling cast, time intervals between cast recovery and sample freezing and fixation and the effect of decompression, could also affect the measurement of actual amo $A$ expression in deep sea (Yakimov et al., 2009).

Deep-sea Crenarchaeota-specific genes encoding NirK The three genes (Nmar_1500,_1503 and _1502) annotated as amoA, amoB and amoC and coding for a putative ammonia monooxygenase complex are the only recognizable genetic hallmarks of $\mathrm{NH}_{4}^{+}$ oxidation in recently published genome sequence of N. maritimus SCM1 (Walker et al., 2010). Using available public databases of marine (meta) genomes, we attempted to compare the genomic context of $N$. maritimus SCM1 amo gene cluster with two bathypelagic microbial communities sampled out at Station ALOHA in the North-Pacific Subtropical Gyre $(4000 \mathrm{~m})$ and at the Eastern Mediterranean Station KM3 (3000 m) (MartinCuadrado et al., 2007, 2008; Konstantinidis et al., 2009). Two deep-sea ALOHA fosmids, HF4000_ APKG4H17 and HF4000_APKG3E18 contained an incomplete $a m o A B$ operon along with the stretch of several predicted open reading frames highly syntenic at the amino-acid level to a $11-\mathrm{Kb}$ genomic fragment situated downstream of the $N$. maritimus SCM1 amoACB operon (Supplementary Figure S2). The psi-BLAST and tBLASTX searches for $N$. maritimus SCM1 amoC homologs, revealed the presence of a relevant sequence in HF4000_ ANIW97M7 fosmid recovered from the ALOHA deepsea database. Downstream of amoC-like sequence, this fosmid predicted to encode a cupredoxin-containing oxidase related to the $N$. maritimus SCM1 nitrite reductases (NirKs) (Nmar_1259 and Nmar_1667, Walker et al., 2010) (Supplementary Figure S2).

As downstream components of a potential $\mathrm{NH}_{4}^{+}$ oxidation pathway, copper containing NirK could have a function in either determining tolerance to nitrite or under limiting oxygen concentrations, allow to use nitrite reduction as an alternative respiratory electron sink (Bartossek et al., 2010; Walker et al., 2010). All sequences available from the databases and potentially attributed to marine
Crenarchaeota possess high level of intra-cluster identity both at the nucleotide and amino-acid levels. On the basis of this finding, the pair of degenerated primers specific for marine crenarchaeal nirK sequences was designed (Supplementary Table S2) and nirK amplicon was obtained from $3480 \mathrm{~m}$ environmental DNA. Phylogenetic analyses of 40 clones demonstrated that all sequences but one were associated with the 'Deep Marine nirK Clade' originally formed by putative NirK genes found in three ALOHA fosmids. The remaining nirK clone was affiliated with $N$. maritimus genes and GOS sequences retrieved from superficial seawater. Both marine nirK clades were represented by the sequences retrieved exclusively from epi and bathypelagic seawater, and exhibited high divergence with 'soil' and 'thermophilic' crenarchaeal and bacterial nirK clades (Figure 3).

According to the predictions of MacPherson and Murphy (2007), the absence of four histidine residues at positions $\mathrm{His}^{43}$, $\mathrm{His}^{87}$, $\mathrm{His}^{270}$ and $\mathrm{His}^{321}$ (Achromobacter cycloclastes NirK numbering), required for trinuclear copper coordination, strongly suggests that NirK-like proteins of 'marine' lineages are NirKs and not multicopper oxidases. Such His-containing multicopper oxidase (CENSYa_1582) was initially annotated as NirK in the genome of C. symbiosum (Hallam et al., 2006a, b), the marine sponge symbiont, which is actually lacking NirK (Bartossek et al., 2010). Although the role of NirK still has to be elucidated for both $\mathrm{NH}_{4}^{+}$-oxidizing bacteria and archaea, the NirK protein likely comprises a part of a defense mechanism against nitrosative intoxication similar to that of its bacterial counterpart (Cantera and Stein, 2007).

\section{Molecular signatures of urea uptake system in Mediterranean bathypelagic crenarchaea}

The deep Mediterranean Sea is permanently nutrientdeprived and one of the most oligotrophic marine ecosystems with ammonium concentrations significantly below $10 \mathrm{nM}$ (Woodward, 1994). However, marine Crenarchaeota seem to be adapted to thrive under such extreme nutrient limitation via possessing the remarkably high affinity towards $\mathrm{NH}_{4}^{+}$(Martens-Habbena et al., 2009) and the metabolic capacity to use as electron donors the reduced $\mathrm{N}$, other than $\mathrm{NH}_{4}^{+}$, for example, urea and amino acids (Hallam et al., 2006b). Two adjacent operons encoding three core urease subunits ureCBA and five urease accessory proteins ureDEFGH were identified in genome of $C$. symbiosum A along with urea transporter (CENSYa_0457) (Hallam et al., 2006b). N. maritimus SCM1 lacks these genes, whereas urease operons with similar arrangements of open reading frames coding for urease subunits were found in two highly syntenic fragments in fosmids, HF4000_ANIW133O4 and HF4000_ APKG7F11, in the ALOHA data set (North-Pacific Subtropical Gyre, $4000 \mathrm{~m}$ depth). The GOS database 
also contains several genomic fragments for urease subunits, but none was found to contain integral ure operon (Supplementary Figure S2).

The ureC gene encodes the $\alpha$-subunit of urease containing an active site and conserved nickel-binding ligands; these conserved regions were suitable targets for primer design to obtain ureC-like sequences from bathypelagic waters from
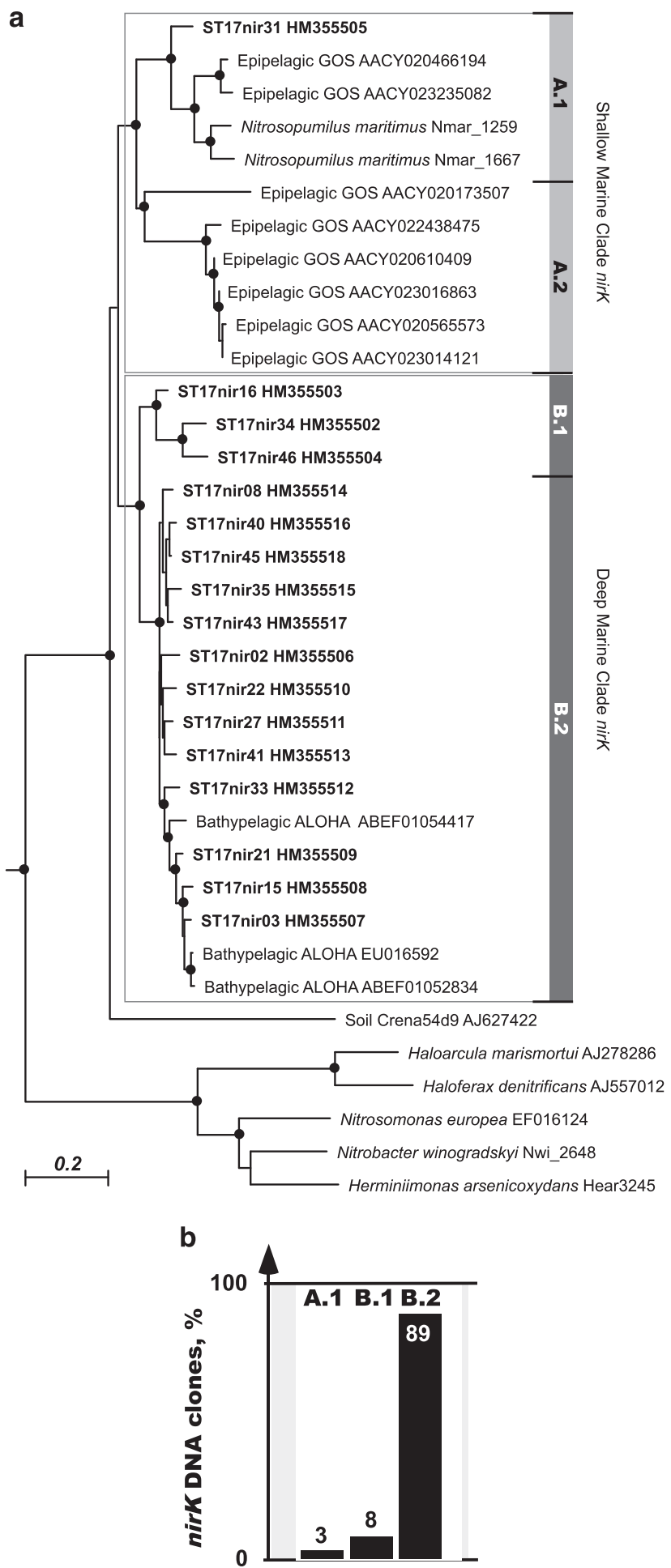

Station 17 (Supplementary Table S2). Recovered gene sequences and ureC-like sequences available from the public databases were used to make phylogenetic inferences. In total, 84 of 93 sequenced clones were found to be affiliated with four related sub-clades and were similar to ureC homologs in two deep-sea fosmids from ALOHA Station, namely HOTS_contig35539 and HF4000ANIW13304 (Figure 4). One numerically minor group of clones ( $6 \%$ of all clones sequenced) was clustered with sequences from GOS shallow water data set. Both clades formed distinct monophyletic groups distantly related to the two ure $C$ genes found in $C$. symbiosum A genome. As it can be seen in Figures 2-4, the tree topology of TDW crenarchaeal ureC gene sequences was strikingly similar to those of amo $A$ and nirK genes pointing to the occurrence of at least two vertically segregated groups of phylogenetically distinct crenarchaeal Shallow and Deep Marine clades.

Estimation of dark ocean primary production rates The rates of prokaryotic dark primary production in seawater column at Station 17 were estimated by incorporation of ${ }^{14} \mathrm{C}$-labeled bicarbonate into the microbial biomass. As described previously (Herndl et al., 2005; Yakimov et al., 2007, 2009), it was assumed that inorganic $\mathrm{C}$ is the only form of $\mathrm{C}$ available to autotrophic prokaryotes and that $\left[{ }^{14} \mathrm{C}\right] \mathrm{HCO}_{3}$ would be taken up by these organisms at the same rates as natural bicarbonates. As shown in Figure 5, dark primary production strongly depends on the type of water masses encompassing the column. Superficial Modified Atlantic Water is characterized by the lower carbon fixation activity compared with Levantine Intermediate Water intermediate layer. The Levantine Intermediate Water masses are formed in Levantine Sea and, in contrast to their high oligotrophy, seemed to be among the most primary productive water masses of Mediterranean Sea (Yakimov et al., 2007). Downward $2000 \mathrm{~m}$, within the layer of TDW, autotrophic

Figure 3 Phylogenetic relationships of crenarchaeal nirK-like sequences retrieved from the depth of $3480 \mathrm{~m}$ at Station 17 in Tyrrhenian Sea: (a) The tree was constructed using both archaeal and bacterial nirK gene sequences of comparable regions available in public databases. The tree is rooted and out-grouped with multicopper oxidases CENSYa_1582 and Nmar_1663 (DP000238.1 and CP000866.1), respectively. Neighbor-Joining analysis using 1000 bootstrap replicates was used to infer tree topology and the nodes with the percentage of bootstrap re-sampling above $75 \%$ is indicated by filled cycles. Phylogenetic trees constructed by other algorithms (maximum parsimony and maximum likelihood) resulted in identical topologies for principal clade grouping. The scale bar represents $20 \%$ nucleotide sequence divergence. Abbreviation used: ALOHA, North Pacific Subtropical Gyre ALOHA station; GOS, Global Ocean Sampling. (b) Percentage of deep Mediterranean crenarchaeal nirK genes to cluster within two Marine Clades originally formed by the sequences retrieved from epi- (GOS) and bathypelagic (ALOHA) zones. Two subgroups are defined within each of these Clades. 


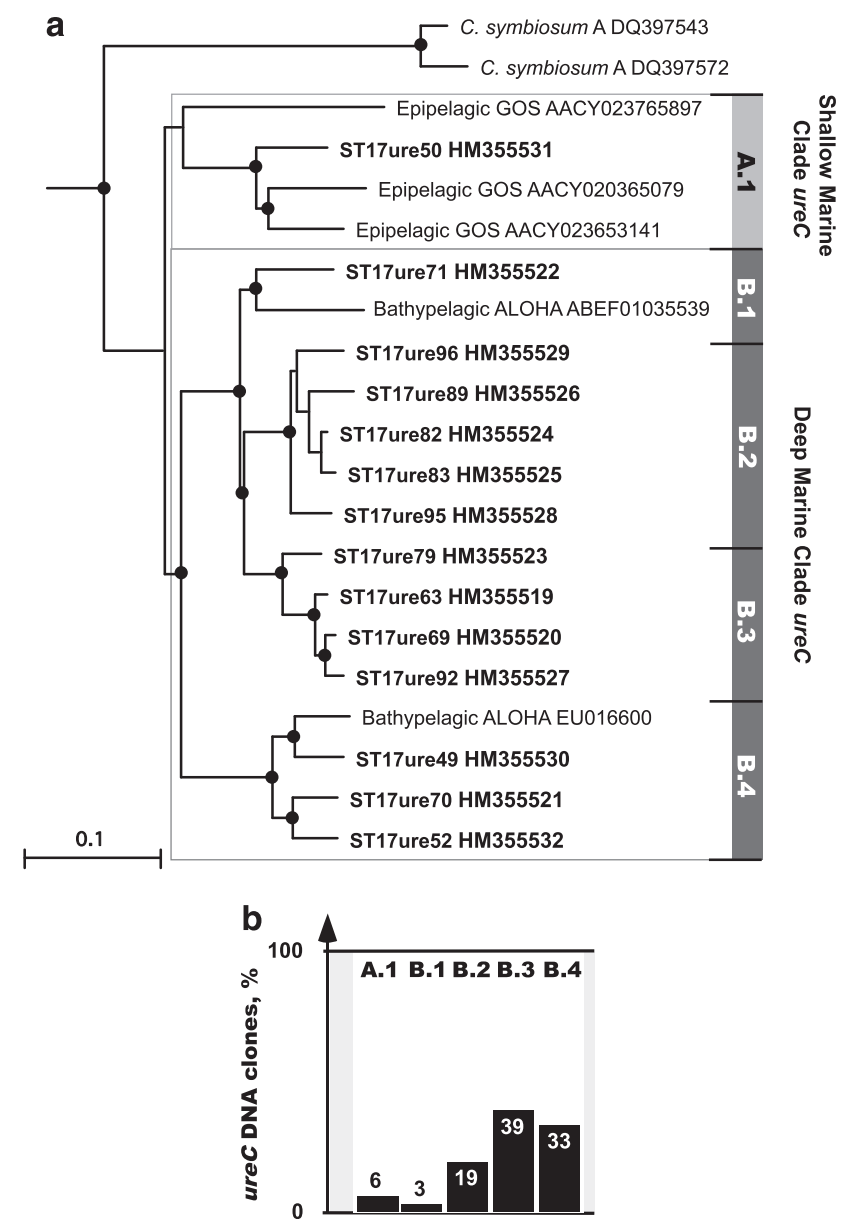

Figure 4 Phylogenetic relationships of crenarchaeal ureC-like sequences retrieved from the depth of $3480 \mathrm{~m}$ at Station 17 in Tyrrhenian Sea: (a) The tree was constructed using marine crearchaeal sequences of comparable regions available in public databases. The tree is rooted and out-grouped with ureC sequences of Alteromonas sp. Deep and E. coli (CP001103 and AE005174), respectively. Neighbor-Joining analysis using 1000 bootstrap replicates was used to infer tree topology and the nodes with the percentage of bootstrap re-sampling above $75 \%$ is indicated by filled cycles. Phylogenetic trees constructed by maximum parsimony algorithm resulted in identical topologies for principal clade grouping. The scale bar represents $10 \%$ nucleotide sequence divergence. Abbreviation used: ALOHA, North Pacific Subtropical Gyre ALOHA station; GOS, Global Ocean Sampling. B. Percentage of deep Mediterranean crenarchaeal nirK genes affiliated to two Marine Clades originally formed by the sequences retrieved from epi- (GOS) and bathypelagic (ALOHA) zones.

activity declined to the values of $50-60 \mu \mathrm{gC} \mathrm{m}{ }^{-3}$ per day and remained constant down to the sea bed (Figure 5). The deep-sea dark $\mathrm{CO}_{2}$ fixation values measured in our study corroborated with earlier estimates $\left(72.0 \pm 8.9 \mu \mathrm{gC} \mathrm{m}{ }^{-3}\right.$ per day) determined in this area at the depth of $3000 \mathrm{~m}$ (Tamburini et al., 2009) and seem to be a characteristic feature of TDW, representing the densest, oldest and highly oligotrophic deep water masses of Mediterranean Sea (Millot et al., 2006). By applying of obtained values to whole aphotic water column (from $200 \mathrm{~m}$ to the seafloor), we estimated the mean dark ocean

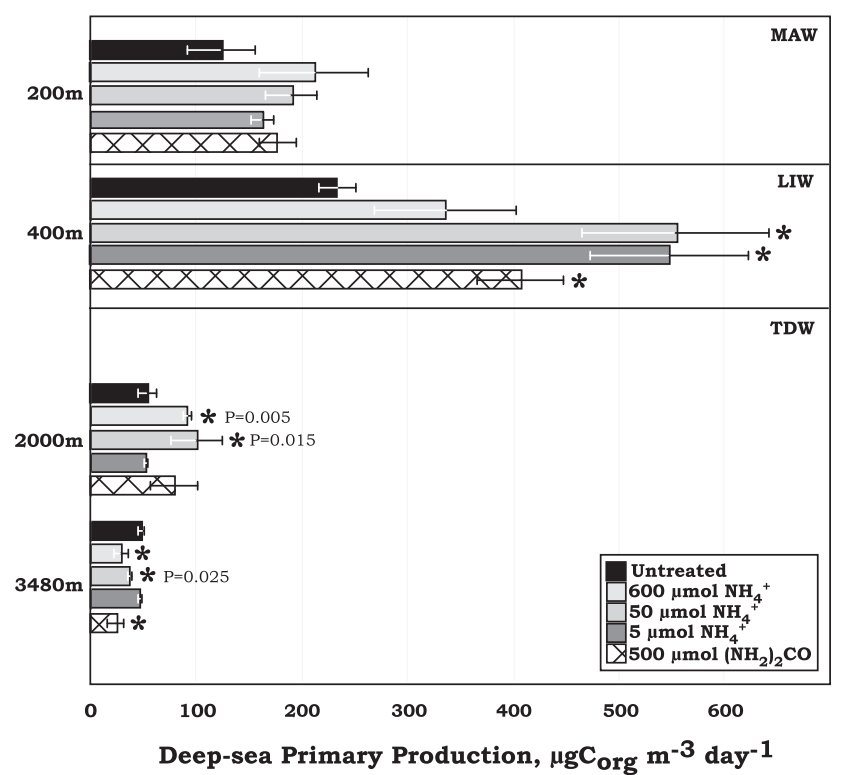

Figure 5 Prokaryotic primary production rates measured in samples taken at Station 17 from different depths and influence of different concentration of added ammonium (5, 50 and $600 \mu \mathrm{mol})$ and urea $(500 \mu \mathrm{mol})$ on bicarbonate fixation activities. All error bars indicate one standard error from a mean of three replicate measurements. One-way analysis of variance (ANOVA test) was applied to analyse the obtained values. The values, significantly different from those of untreated samples, are indicated by asterisks. Resulting $P$-values different from $P<0.001$ are indicated.

production at Station 17 as $257 \mathrm{mgCm}^{-2}$ per day, which is comparable to the median value of photosynthetic biomass production (273-429 $\mathrm{mgC} \mathrm{m}^{-2}$ per day) calculated for this area of Tyrrhenian Sea (Decembrini et al., 2009). This observation pointed at both, the significance of the dark ocean primary production in the carbon cycle in aphotic marine ecosystems and at the nature of potential source of energy fueling this process.

Addition of various concentrations of $\mathrm{NH}_{4}^{+}$had similar positive effect on $\left[{ }^{14} \mathrm{C}\right] \mathrm{HCO}_{3}$ fixation rates in epipelagic water masses, independently on amount of $\mathrm{NH}_{4}^{+}$applied (Figure 5). The autotrophic prokaryotes inhabiting the OMZ layer were strongly stimulated by low concentrations of ammonium. The increase of $\mathrm{CO}_{2}$ fixation was also observed with $600 \mu \mathrm{mol} \mathrm{l}^{-1}$, although in a lesser extent. In contrast, the autotrophy of mesopelagic community was insignificantly activated by higher concentration of $\mathrm{NH}_{4}^{+}$and no influence on $\mathrm{CO}_{2}$ fixation was detected after addition of $5 \mu \mathrm{moll}^{-1}$. Same indifferent response to addition of $5 \mu \mathrm{mol} \mathrm{l}^{-1}$ ammonia was obtained for bathypelagic lithoautotrophic community. This community seemed to possess high sensitivity to ammonia: statistically significant inhibition of $\mathrm{CO}_{2}$ fixation was detected at concentrations of $\mathrm{NH}_{4}^{+}$higher than $5 \mu \mathrm{mol}$ (Figure 5).

The finding of marine crenarchaeal-specific ureC genes encoding urease $\alpha$-subunit in deep Mediterranean Sea is consistent with the hypothesis that 
marine Crenarchaeota are capable of using urea as a reduced $\mathrm{N}$ form for amino-acid biosynthesis, energy production or both (Hallam et al., 2006b; Church et al., 2010). We tested this hypothesis by addition of $500 \mu \mathrm{moll}^{-1}$ of urea to the seawater samples and measured $\left[{ }^{14} \mathrm{C}\right] \mathrm{HCO}_{3}$ fixation rates were compared with those of untreated and $\mathrm{NH}_{4}^{+}$-supplemented experiments. As it can be seen in Figure 5, urea has influenced the primary production in a manner, absolutely identical to addition of comparable amount of $\mathrm{NH}_{4}^{+}\left(600 \mu \mathrm{moll}{ }^{-1}\right)$. The stimulating effect of urea on dark primary production has not been demonstrated so far. Even though there is a further need in elucidation of the mechanism of this phenomenon, our observation indicates that autotrophic members of deep-sea microbial community can catabolize urea to fuel their metabolism.

\section{Influence of various factors and additives on dark} primary production rates

The effect of various additives on autotrophic activity of bathypelagic microbial community collected at depth of $3480 \mathrm{~m}$ was examined in more detail (Figure 6). Similarly to other members of Eury- and Crenarchaeota (Jolivet et al., 2003; Simon et al., 2005; Pikuta et al., 2007), the addition of rifampicin $\left(100 \mu \mathrm{g} \mathrm{ml}^{-1}\right)$, an antibiotic agent inactivating prokaryotic DNA-dependent RNA polymerase, completely inhibited $\mathrm{CO}_{2}$ fixation, whereas there was no toxic effect of radicicol $\left(20 \mu \mathrm{g} \mathrm{ml}^{-1}\right)$, a natural product that inhibits DNA topoisomerase IV

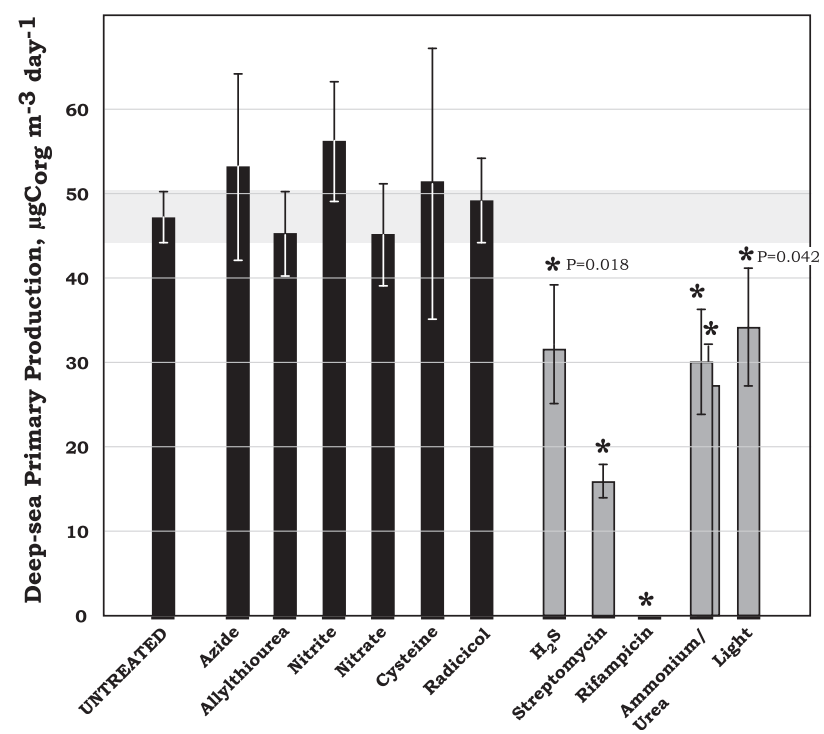

Figure 6 Influence of various additives and physical factors on primary production rates measured in seawater samples collected at $3480 \mathrm{~m}$. The concentrations of all additives are given in corresponding part of Materials and methods section. All error bars indicate one standard error from a mean of three replicate measurements. Student's t-test was applied to analyze the obtained values. The values, significantly different from those of untreated samples, are indicated by asterisks. Resulting $P$-values different from $(P<0.001)$ are indicated. of some thermophilic crenarchaea (Gadelle et al., 2005). Depletion of oxygen in the deep seawater samples by addition of sulfide caused a slight decrease in primary production rates compared with untreated control $(P=0.018)$. This negative effect should be ascribed to the toxic effect of sulfide (Erguder et al., 2009) rather than to oxygen depletion. Indeed, an addition of DL-cysteine could potentially have lead to the establishment of a micro-aerophilic environment $\left(45 \mu \mathrm{mol} \mathrm{O}_{2} \mathrm{l}^{-1}\right)$, but it had no significant influence on bicarbonate fixation (Figure 6). The exposure of the deep seawater samples to full daylight (12000 lux) also had a slightly negative effect on primary production rates $(72 \pm 15 \%$ productivity of the control, $P=0.042)$. As was recently proposed (Mincer et al., 2007; Church et al., 2010), this effect could be explained by partial photo-inhibition of deep-sea AmoA proteins.

Addition of either nitrate or nitrite appeared to have no effect on bicarbonate fixation rates. As it was already demonstrated for the ammoniaoxidizing thermophilic crenarchaea (Hatzenpichler et al., 2008), an addition of $86 \mu \mathrm{M}$ allylthiourea, known inhibitor of bacterial ammonium monooxygenase, did not cause significant decline in autotrophic activity of deep-sea Crenarchaeota. Albeit the sodium azide has been also shown to inhibit bacterial ammonia and nitrite oxidation (Ginestet et al., 1998), its addition had no significant influence on bicarbonate fixation at least given experimental conditions, thus suggesting the minor role of bacteria in observed autotrophy.

\section{Molecular signatures of autotrophic pathways in Mediterranean bathypelagic crenarchaea}

To analyse the distribution of $\mathrm{CO}_{2}$-fixing prokaryotes, the presence of crucial genes involved in autotrophic pathways was monitored across the water column. Six mechanisms are currently known by which autotrophic organisms can fix the inorganic carbon (Huber et al., 2008; Berg et al., $2010 a, b)$. Because of the general sensitivity of the corresponding enzymes to the oxygen, only two pathways, namely Calvin-Benson-Bassham and 3-hydroxypropionate/4-hydroxybutyrate (3-HP/4-HB) cycles, could occur in oxygenated seawater (Thauer, 2007; Berg et al., 2007, 2010a,b). Specially designed and previously tested primer pairs (Elsaied and Naganuma, 2001; Yakimov et al., 2007) were used to amplify the fragment of bacterial genes encoding the large subunit of red and green-like form I RuBisCO (CbbL), the key enzyme of Calvin-Benson-Bassham cycle (See Supplementary Table S2). Except OMZ (400 $\mathrm{m}$ depth), no amplification products were observed at any depth, indicating the presence of Calvin-Benson-Bassham cycle-operating prokaryotes only within oxygen-depleted layer. All $20 \mathrm{cbbL}$ clones sequenced were found to be identical and deeply branched within cluster of autotrophic $\beta$-Proteobacteria (Supplementary Figure S3). The occurrence 


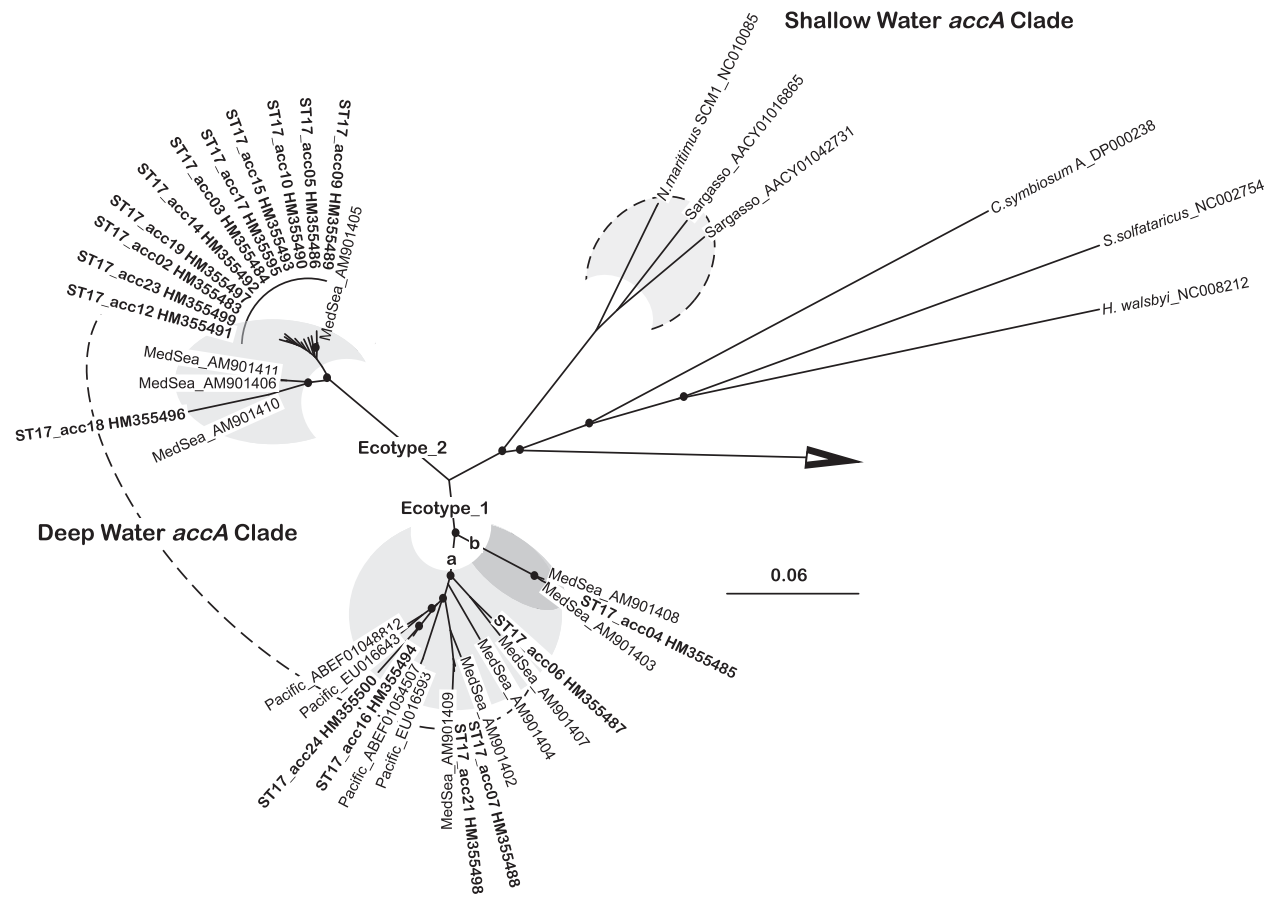

Figure 7 Phylogenetic relationships of crenarchaeal accA-like sequences retrieved from $3480 \mathrm{~m}$ depth at Station 17 in Tyrrhenian Sea. The tree was constructed using archaeal sequences of comparable regions available in public databases. The tree is rooted and outgrouped with accA sequence of Caldicellulosiruptor saccharolyticus (CP000679). Neighbor-Joining analysis using 1000 bootstrap replicates was used to infer tree topology and the nodes with the percentage of bootstrap re-sampling above $70 \%$ is indicated by filled cycles. The scale bar represents $6 \%$ nucleotide sequence divergence.

of $\mathrm{NH}_{4}^{+}$-oxidizing betaproteobacteria belonging to Nitrosospira and Nitrosococcus was already demonstrated in the oceanic OMZs worldwide (Lam et al., 2007 , 2009). Unfortunately, we were not able to affiliate our $c b b L$-like sequences to either sulphur-, metal- or $\mathrm{NH}_{4}^{+}$-respiring bacteria, thus, the type of energygaining pathway, utilized by autotrophic betaproteobacteria in the OMZ of Station 17, remained unclear.

In contrast to RuBisCO, the genes coding for crenarchaeal AccA, the key enzyme in autotrophic 3-HP/4-HB pathway, were retrieved from all sampled layers (data not shown). The pool of accA-like genes amplified from $3480 \mathrm{~m}$ is represented by two different ecotypes previously detected in this area (Yakimov et al., 2009). The majority of accA-like clones (39 of 57 clones analyzed) were affiliated with a uniquely Mediterranean 'Ecotype_2' (Yakimov et al., 2009) with no similar sequences known (Figure 7). The rest of accA-like clones formed the 'Ecotype_1', which also includes the sequences from bathypelagic seawater (4000 m depth) from North Pacific Subtropical Gyre, Hawaii Ocean Time Series Station ALOHA (DeLong et al., 2006; Mincer et al., 2007). As it is the case with the meso- and bathypelagic crenarchaeal amoA, nirk and ure $C$ genes, both accA clades are separated from $N$. maritimus SCM1, C. symbiosum $A$ and from the cluster of sequences found in superficial waters of Sargasso Sea (Figure 7), indicating the possible occurrence of at least two vertically separated groups of phylogenetically distinct shallow and deep planktonic Crenarchaeota.

As stated by Berg et al. (2010a,b) the second key enzyme unambiguously indicating the presence of autotrophic 3-HP/4-HB pathway is the 4-HBD. Originally this enzyme was described in a few strict fermentative anaerobes, but recently 4-HBD has been postulated to be a pivotal enzyme in $\mathrm{CO}_{2}$ fixing 3H-P/4-HB cycle in autotrophic thermophilic and, possibly, also in mesophilic Crenarchaeota (Huber et al., 2008; Berg et al., 2007, 2010a,b). On the basis of the sequence similarities of these genes in N. maritimus SCM1 and C. symbiosum A genomes, we have found the 4-HBD homologs encoded in fosmids of bathypelagic ALOHA Station and in GOS contigs (La Cono et al., 2010). Using the primer pair specifically targeting all marine crenarchaeal 4- $h b d$ sequences, we were able to amplify this gene from the environmental DNA collected from $3480 \mathrm{~m}$. All 20 clones analyzed harbored 4-hbd genes very similar each to another and to that coding for the putative 4-hydroxyphenylacetate 3-hydroxylase protein of uncultured marine crenarchaeote HF4000 APKG3H9. As in the case with $a c c \mathrm{~A}$, retrieved $4-h b \bar{d}$ genes formed a tight cluster with the bathypelagic sequences, whereas a very distant relation was observed with those of 'shallow' representatives of marine crenarchaea exhibiting only 82 and $73 \%$ protein sequence identity with $N$. maritimus SCM1, C. symbiosum, respectively (Figure 8). Remarkably, 


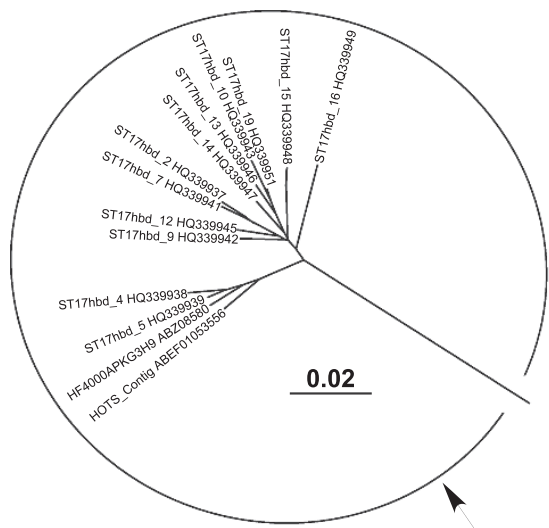

Figure 8 Phylogenetic affiliation of putative 4-hydroxybutyryl-CoA dehydratases 4-HBD recovered from deep Tyrrhenian Sea (3480 m) as determined by Neighbor-Joining analysis and Poisson correction of distances. The clones attributed to deep-sea Crenarchaeota lineage are shown in details in the insert. The tree is out-grouped with 3-hydroxybutyryl-CoA dehydrogenase of N. maritimus SCM1 (Nmar_1028, ABX12924). Neighbor-Joining analysis using 1000 bootstrap replicates was used to infer tree topology and the nodes with the percentage of bootstrap re-sampling above $70 \%$ are indicated. The scale bar represents percentage of amino-acid sequence divergence.

the 'mesophilic' marine crenarchaeal sequences are no more similar considering either their sequences or chromosomal arrangements, to 'thermophilic' crenarchaeal 4-hbd genes than they are to the homologs genes encoding bacterial dehydratases, suggesting functional and evolutionary differences between the 'mesophilic' and 'thermophilic' versions of crenarchaeal 4-HBD. This observation is coincident with a hypothesis that marine autotrophic archaea are likely the representatives of an evolutionary lineage different from Crenarchaea (Brochier-Armanet et al., 2008; Gupta and Shami, 2010; Spang et al., 2010).

\section{Study of $\left[{ }^{14} \mathrm{C}\right] \mathrm{HCO}_{3}$ assimilation using shotgun} metaproteomic analysis

Carbon assimilation mechanisms predominant in the bathypelagic zone and the exact role of marine crenarchaeota in this process have yet to be elucidated. The possibility of heterotrophic growth of marine crenarchaea is supported by studies that demonstrating the incorporation of ${ }^{14} \mathrm{C}$-labeled amino acids into the cells of marine crenarchaea (Ouverney and Fuhrman, 2000; Herndl et al., 2005). In contrast, incorporation of ${ }^{13} \mathrm{C}$-labeled bicarbonate into the archaeal membrane lipids (Wuchter et al., 2003) and archaeal cells (Herndl et al., 2005) and the natural radiocarbon content of archaeal lipids from the marine water column (Pearson et al., 2001; Ingalls et al., 2006) support the view of a predominantly autotrophic metabolism of marine crenarchaea. Recent isolation and genome analysis of N. maritimus SCM1 (Könneke et al., 2005; Walker et al., 2010) support the latter view. In the present study, we attempted to pair the molecular data with functional studies of microbial processes and with ${ }^{14} \mathrm{C}$-labeled bicarbonate incorporation experiments by using a shotgun proteomic approach. Highpressure liquid chromatography with combined ultraviolet and on-line flow-through radioactivity detection system was used for monitoring and separation of ${ }^{14} \mathrm{C}$-labeled proteins from not labeled material. After pooling, the radioactive proteins were subjected to trypsin digestion and the obtained peptides were analyzed using reverse phase liquid chromatography-tandem mass spectrometry. Compared with traditional proteomic methods, the application of this combined technique provides a powerful tool for proteome profiling and biomarker discovery. About 40 different proteins were properly attributed to marine Crenarchaeota, including hits from both $N$. maritimus SCM1, C. symbiosum A genomes and from the fosmids of bathypelagic waters of Pacific Ocean and Mediterranean Sea. The number of peptides per identified protein ranged from one to seven and the percentage of protein 


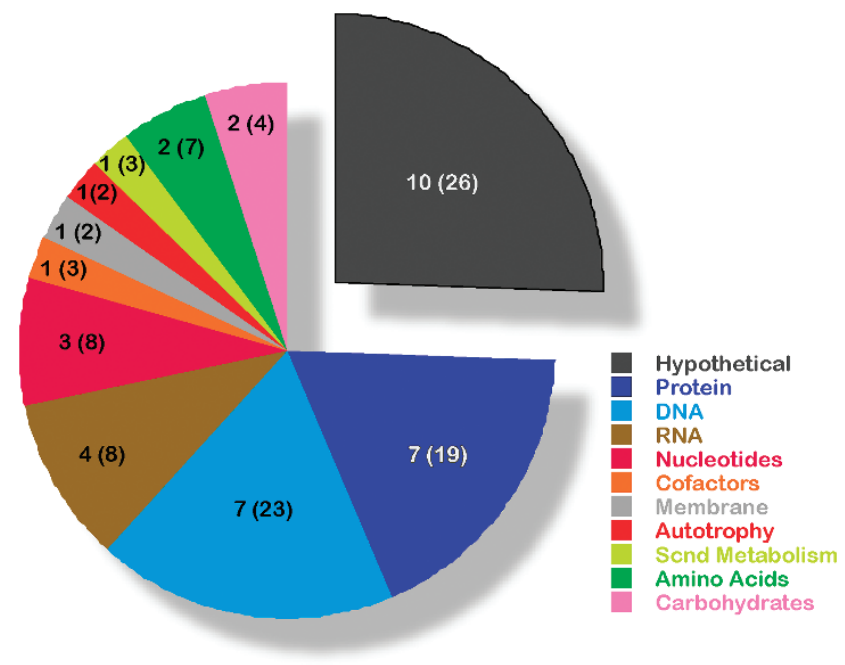

Figure 9 Number of identified crenarchaeal-specific ${ }^{14} \mathrm{C}$ labeled proteins and oligopeptide density grouped as clusters of orthologues genes (COGs). Abbreviations used for COGs: protein, posttranslational modifications and translation, ribosomal structure and biogenesis; DNA/RNA, replication, recombination and repair, transcription, genetic information processing, RNA degradation; nucleotide, nucleotide transport and metabolism; cofactors, coenzyme transport and metabolism; membrane, intracellular trafficking and secretion; inorganic ion transport and metabolism; scnd metabolism, secondary metabolites biosynthesis and transport, amino acids, amino-acid transport and metabolism; carbohydrate, carbohydrate transport and metabolism. Autotrophy stands for 4-hydroxybutyryl-CoA dehydrase, a key enzyme of 3-HP/4-HB autotrophic pathway.

amino-acid sequence coverage by the identified peptide(s) ranged from 2.2 to $65.1 \%$, approximately (see Supplementary Table S3).

From the standpoint of energy metabolism, aerobic $\mathrm{NH}_{4}^{+}$oxidation is a relatively low energy-gaining process, thus, the energy limitation exerts a strong selective pressure in favor of energy-saving mechanisms and the energy costs are primarily spent for the synthesis of enzymes taking part of the basal cell's machinery and autotrophy (Berg et al., 2010a). At least some part of bathypelagic Crenarchaeota possess an $\mathrm{NH}_{4}^{+}$-based chemolithoautotrophic energy metabolism, and thus, the biosynthesis of these enzymes, especially the auxiliary $\mathrm{CO}_{2}$ fixation-related ones, should be considered vital for these organisms. As it is shown in Figure 9, the identified crenarchaeaspecific proteins are involved in at least 10 different biological processes with the absolute prevalence of DNA/RNA and protein metabolism-related enzymes (45\%). Besides DNA and RNA polymerases, two helicases similar to those of $C$. symbiosum A (CENSYa_0180 and CENSYa_1010) were identified (Supplementary Table S3). At least 15 oligopeptides were attributed to four proteins of different chaperone systems indicating the importance of the folding pathways in crenarchaeal metabolism. Remarkably, of all the peptides subjected to shotgun proteomic we were able to identify two 9 and 19 amino-acid-long oligopeptides, unambiguously attributed to 4-HBD, a key enzyme involved in autotrophic carbon fixation via 3-hydroxypropionate/4-hydroxybutyrate cycle (Berg et al., 2010a,b). It should be noted that significant amount of resolved oligopeptides (25\%) were assigned to 10 hypothetical marine crenarchaeaspecific proteins of unknown function, thus precluding any speculation about their role in the cellular processes.

\section{Conclusion}

In the present work, we studied a number of issues related to dark ocean primary production driven, at least partially, by marine Crenarchaeota. Marine mesophilic Crenarchaeota are actively growing in the oxygenated water column of Tyrrhenian Sea using bicarbonate as a $\mathrm{C}$ source. The estimated mean dark ocean production at Station 17 was shown be comparable to the median value of photosynthetic biomass production calculated for this area of Tyrrhenian Sea. Therefore, this group of chemoautotrophic prokaryotes, numerically dominating deep-sea microbial communities worldwide, might represent an important and hitherto unrecognized driver for sink of inorganic carbon in the largest oceanic subsystem embracing mesopelagic and bathypelagic zone. The resistance of marine Crenarchaeota to cultivation limits our capacities to unravel and define specific processes controlling their physiology and abundance. Therefore, further studies, including metagenomic and proteomic approaches and cultivation under in situ conditions, are necessary to overcome this circumstance and to provide important new insights into the mechanisms of element cycling in the deep-sea environment.

\section{Acknowledgements}

We thank the captain and the crew of RV Urania for their expert handling of our equipment during the cruise and for highly productive technical assistance. This study was supported by the European Science Foundation Programme EuroCORES/EuroDEEP under MIDDLE project (06-EuroDEEP-FP-004), by European Community Project MAMBA (FP7-KBBE-2008-226977) and Spanish CSD200700005 Project.

\section{References}

Agogué H, Brink M, Dinasquet J, Herndl GJ. (2008). Major gradients in putatively nitrifying and non-nitrifying archaea in the deep North Atlantic. Nature 456: 788-791.

Altschul SF, Madden TL, Schaffer AA, Zhang J, Zhang Z, Miller W et al. (1997). Gapped BLAST and PSI-BLAST: a new generation of protein database search programs. Nucleic Acids Res 25: 3389-3402.

Amann R, Ludwig W, Schleifer K. (1995). Phylogenetic identification and in situ detection of individual microbial cells without cultivation. Microbiol Rev 59: 143-169. 
Bartossek R, Nicol GW, Lanzen A, Klenk HP, Schleper C. (2010). Homologues of nitrite reductases in ammoniaoxidizing archaea: diversity and genomic context. Environ Microbiol 12: 1075-1088.

Beman JM, Popp BN, Francis CA. (2008). Molecular and biogeochemical evidence for ammonia oxidation by marine Crenarchaeota in the Gulf of California. ISME J 2: 429-441.

Berg IA, Kockelkorn D, Buckel W, Fuchs G. (2007). A 3-hydroxypropionate/4-hydrdoxybutyrate autotrophic carbon dixide assimilation pathway in Archaea. Science 318: 1782-1786.

Berg IA, Kockelkorn D, Ramos-Vera WH, Say RF, Zarzycki J, Hügler M et al. (2010a). Autotrophic carbon fixation in archaea. Nat Rev Microbiol 8: 447-460.

Berg IA, Ramos-Vera WH, Petri A, Huber H, Fuchs G. (2010b). Study of the distribution of autotrophic $\mathrm{CO}_{2}$ fixation cycles in Crenarchaeota. Microbiology 156: 256-269.

Brochier-Armanet C, Boussau B, Gribaldo S, Forterre P. (2008). Mesophilic Crenarchaeota: proposal for a third archaeal phylum, the Thaumarchaeota. Nat Rev Microbiol 6: 245-252.

Cantera JJ, Stein LY. (2007). Role of nitrite reductase in the ammonia-oxidizing pathway of Nitrosomonas europaea. Arch Microbiol 188: 349-354.

Carpenter JH. (1965). The accuracy of the Winkler method for the dissolved oxygen analysis. Limnol Oceanogr 10: $135-140$.

Church MJ, Wai B, Karl DM, DeLong EF. (2010). Abundances of crenarchael amoA genes and transcripts in the Pacific Ocean. Environ Microbiol 12: 679-688.

Cole JR, Chai B, Farris RJ, Wang Q, Kulam SA, Mcgarrell DM et al. (2005). The Ribosomal Database Project (RDP-II): Sequences and tools for highthroughput rRNA analysis. Nucleis Acids Res 33: D294-D296.

De Corte D, Yokokawa T, Varela MM, Agogué H, Herndl GJ. (2009). Spatial distribution of Bacteria and Archaea and amoA gene copy numbers throughout the water column of the Eastern Mediterranean Sea. ISME $J$ 3: 147-158.

de la Torre JR, Walker CB, Ingalls AE, Könneke M, Stahl DA. (2008). Cultivation of a thermophilic ammonia oxidizing archaeon synthesizing crenarchaeol. Environ Microbiol 10: 810-818.

Decembrini F, Caroppo C, Azzaro M. (2009). Size structure and production of phytoplankton community and carbon pathways channelling in the Southern Tyrrhenian Sea (Western Mediterranean). Deep-Sea Res II 56: 687-699.

DeLong EF, Preston CM, Mincer T, Rich V, Hallam SJ, Frigaard NU et al. (2006). Community genomics among stratified microbial assemblages in the ocean's interior. Science 311: 496-503.

Elsaied H, Naganuma T. (2001). Phylogenetic diversity of ribulose-1,5-bisphosphate carboxylase/oxygenase large subunit genes from deep-sea microorganisms. Appl Environ Microbiol 67: 1751-1765.

Erguder TH, Boon N, Wittebolle L, Marzorati M, Verstraete W. (2009). Environmental factors shaping the ecological niches of ammonia-oxidizing archaea. FEMS Microbiol Rev 33: 855-869.

Francis CA, Roberts KJ, Beman JM, Santoro AE, Oakley BB. (2005). Ubiquity and diversity of ammonia-oxidizing archaea in water columns and sediments of the ocean. Proc Natl Acad Sci USA 102: 14683-14688.
Gadelle D, Bocs C, Graille M, Forterre P. (2005). Inhibition of archaeal growth and DNA topoisomerase VI activities by the Hsp90 inhibitor radicicol. Nucleic Acids Res 33: 2310-2317.

Ginestet P, Audic J-M, Urbain V, Block J-C. (1998). Estimation of nitrifying bacterial activities by measuring oxygen uptake in the presence of the metabolic inhibitors allylthiourea and azide. Appl Environ Microbiol 64: 2266-2268.

Gupta RS, Shami A. (2010). Molecular signatures for the Crenarchaeota and the Thaumarchaeota. Antonie Van Leeuwenhoek, doi 10.1007/s10482-010-9488-3; Epub ahead of print.

Hallam SJ, Konstantinidis KT, Putnam N, Schleper C, Watanabe Y, Sugahara J et al. (2006a). Genomic analysis of the uncultivated marine crenarchaeote Cenarchaeum symbiosum. Proc Natl Acad Sci USA 103: 18296-18301.

Hallam SJ, Mincer TJ, Schleper C, Preston CM, Roberts K, Richardson PM et al. (2006b). Pathways of carbon assimilation and ammonia oxidation suggested by environmental genomic analyses of marine Crenarchaeota. PLoS Biol 4: e95.

Hatzenpichler R, Lebecleva EV, Spieck E, Stoecker K, Richter A, Daims H et al. (2008). A moderately thermophilic ammonia-oxidizing crenarchaeote from a hot spring. ProcNatl Acad Sci USA 105: 2134-2139.

Herndl GJ, Reinthaler T, Teira E, van Aken H, Veth C, Pernthaler A et al. (2005). Contribution of Archaea to total prokaryotic production in the deep Atlantic Ocean. Appl Environ Microbiol 71: 2303-2309.

Huber H, Gallenberg M, Jahn U, Eylert E, Berg IA, Kockelkorn D et al. (2008). A dicarboxylate/4-hydroxybutyrate autotrophic carbon assimilation cycle in the hyperthermophilic Archaeum Ignicoccus hospitalis. Proc Natl Acad Sci USA 105: 7851-7856.

Ingalls AE, Shah SR, Hansman RL, Aluwihare LI, Santos GM, Druffel ER et al. (2006). Quantifying archaeal community autotrophy in the mesopelagic ocean using natural radiocarbon. Proc Natl Acad Sci USA 103: 6442-6447.

Jolivet E, L'Haridon S, Corre E, Forterre P, Prieur D. (2003). Thermococcus gammatolerans sp. nov., a hyperthermophilic archaeon from a deep-sea hydrothermal vent that resists ionizing radiation. Int J Syst Evol Microbiol 53: 847-851.

Karner MB, Fuhrman J. (1997). Determination of active marine bacterioplankton: a comparison of universal 16S rRNA probes, autoradiography, and nucleoid staining. Appl Environ Microbiol 63: 1208-1213.

Karner MB, DeLong EF, Karl DM. (2001). Archaeal dominance in the mesopelagic zone of the Pacific Ocean. Nature 409: 507-510.

Kirchman DL, Elifantz H, Dittel AI, Malmstrom RR, Cottrell MT. (2007). Standing stocks and activity of Archaea and Bacteria in the western Arctic Ocean. Limnol Oceanogr 52: 495-507.

Könneke M, Bernhard AE, de la Torre JR, Walker CB, Waterbury JB, Stahl DA. (2005). Isolation of an autotrophic ammonia-oxidizing marine archaeon. Nature 437: $543-546$.

Konstantinidis KT, Braff J, Karl DM, DeLong EF. (2009). Comparative metagenomic analysis of a microbial community residing at a depth of 4000 meters at station ALOHA in the North Pacific subtropical gyre. Appl Environ Microbiol 75: 5345-5355. 
La Cono V, Smedile F, Ferrer M, Golyshin PN, Giuliano L, Yakimov MM. (2010). Genomic signatures of fifth autotrophic carbon assimilation pathway in bathypelagic Crenarchaeota. Microb Biotechnol 3: 595-606.

Lam P, Jensen MM, Lavik G, McGinnis DF, Müller B, Schubert CJ et al. (2007). Linking crenarchaeal and bacterial nitrification to anammox in the Black Sea. Proc Natl Acad Sci USA 104: 7104-7109.

Lam P, Lavik G, Jensen MM, van de Vossenberg J, Schmid M, Woebken D et al. (2009). Revising the nitrogen cycle in the Peruvian oxygen minimum zone. Proc Natl Acad Sci USA 106: 4752-4757.

MacPherson IS, Murphy ME. (2007). Type-2 coppercontaining enzymes. Cell Mol Life Sci 64: 2887-2899.

Martens-Habbena W, Berube PM, Urakawa H, de la Torre JR, Stahl DA. (2009). Ammonia oxidation kinetics determine niche separation of nitrifying Archaea and Bacteria. Nature 461: 976-979.

Martin-Cuadrado AB, López-García P, Alba JC, Moreira D, Monticelli L, Strittmatter A et al. (2007). Metagenomics of the deep Mediterranean, a warm bathypelagic habitat. PLoS One 2: e914.

Martin-Cuadrado AB, Rodriguez-Valera F, Moreira D, Alba JC, Ivars-Martínez E, Henn MR et al. (2008). Hindsight in the relative abundance, metabolic potential and genome dynamics of uncultivated marine archaea from comparative metagenomic analyses of bathypelagic plankton of different oceanic regions. ISME J 2: 865-886.

Millot C, Candela J, Fuda J-L, Tber Y. (2006). Large warming and salinification of the Mediterranean outflow due to changes in its composition. Deep-Sea Res pI 53: 656-666.

Mincer TJ, Church MJ, Taylor LT, Preston C, Karl DM, DeLong EF. (2007). Quantitative distribution of presumptive archaeal and bacterial nitrifiers in Monterey Bay and the North Pacific Subtropical Gyre. Environ Microbiol 9: 1162-1175.

Ouverney CC, Fuhrman JA. (2000). Marine planktonic archaea take up amino acids. Appl Environ Microbiol 66: $4829-4833$.

Park BJ, Park SJ, Yoon DN, Schouten S, Sininnghe Damsté JS, Rhee SK. (2010). Cultivation of autotrophic ammonia-oxidizing archaea from marine sediments in co-culture with sulfur-oxidizing bacteria. Appl Environ Microbiol 76: 7575-7587.

Pearson A, McNichol AP, Benitez-Nelson BC, Hayes JM, Eglinton TI. (2001). Origins of lipid biomarkers in Santa Monica Basin surface sediment: A case study using compound-specific $\mathrm{D}^{14} \mathrm{C}$ analysis. Geochimica et Cosmochimica Acta 65: 3123-3137.

Pérez MT, Pausz C, Herndl GJ. (2003). Major shift in bacterioplankton utilization of enantiomeric amino acids between surface waters and the ocean's interior. Limnol Oceanogr 48: 755-763.

Pernthaler A, Pernthaler J, Amann R. (2002). Fluorescence in situ hybridization and catalyzed reporter deposition for the identification of marine bacteria. Appl Environ Microbiol 68: 3094-3101.

Pikuta EV, Marsic D, Itoh T, Bej AK, Tang J, Whitman WB et al. (2007). Thermococcus thioreducens sp. nov., a novel hyperthermophilic, obligately sulfur-reducing archaeon from a deep-sea hydrothermal vent. Int J Syst Evol Microbiol 57: 1612-1618.

Rajagopal I. (2000). SOFTWARE: Genomics made easy. Science 290: 474.
Ribera d'Alcalà M, Brunet C, Convensano F, Corato F, Lavezza R. (2009). Nutrient and pigment distributions in the southern Tyrrhenian Sea during mid-summer and late fall 2005. Deep-Sea Res II 56: 676-686.

Rivaro P, Messa R, Massolo S, Frache R. (2010). Distributions of carbonate properties along the water column in the Mediterranean Sea: spatial and temporal variations. Mar Chem 121: 236-245.

Schleper C. (2008). Metabolism of the deep. Nature 456: $712-714$.

Schloss PD, Handelsman J. (2005). Introducing DOTUR, a computer program for defining operational taxonomical units and estimating species richness. Appl Environ Microbiol 71: 1501-1506.

Sekar R, Fuchs BM, Amann R, Pernthaler J. (2004). Flow sorting of marine bacterioplankton after fluorescence in situ hybridization. Appl Environ Microbiol 70: 6210-6219.

Simon HM, Jahn CE, Bergerud LT, Sliwinski MK, Weimer PJ, Willis DK et al. (2005). Cultivation of mesophilic soil crenarchaeotes in enrichment cultures from plant roots. Appl Environ Microbiol 71: 4751-4760.

Spang A, Hatzenpichler R, Brochier-Armanet C, Rattei T, Tischler P, Spieck E et al. (2010). Distinct gene set in two different lineages of ammonia-oxidizing archaea supports the phylum Thaumarchaeota. Trends Microbiol 18: 331-340.

Tamburini C, Garel M, Al Ali B, Merigot B, Kriwy P, Charriere B et al. (2009). Distribution and activity of Bacteria and Archaea in the different water masses of the Tyrrhenian Sea. Deep-Sea Res pII 56: $700-712$.

Teira E, Lebaron P, van Aken H, Herndl GJ. (2006). Distribution and activity of Bacteria and Archaea in the deep water masses of the North Atlantic. Limnol Oceanogr 51: 2131-2144.

Teira E, Reinthaler T, Pernthaler A, Pernthaler J, Herndl GJ. (2004). Combining catalyzed reporter depositionfluorescence in situ hybridization and microautoradiography to detect substrate utilization by bacteria and archaea in the deep ocean. Appl Environ Microbiol 70: 4411-4414.

Thauer RK. (2007). A fifth pathway of carbon fixation. Science 318: 1732-1733.

Treusch AH, Leininger S, Kletzin A, Schuster SC, Klenk HP, Schleper C. (2005). Novel genes for nitrite reductase and Amo-related proteins indicate a role of uncultivated mesophilic crenarchaeota in nitrogen cycling. Environ Microbiol 7: 1985-1995.

Varela MM, van Aken HM, Sintes E, Herndl GJ. (2008). Latitudinal trends of Crenarchaeota and Bacteria in the meso- and bathypelagic water masses of the Eastern North Atlantic. Environ Microbiol 10: 110-124.

Venter JC, Remington K, Heidelberg JF, Halpern AL, Rusch D, Eisen JA et al. (2004). Environmental genome shotgun sequencing of the Sargasso Sea. Science 304: 66-74.

Walker CB, de la Torre JR, Klotz MG, Urakawa H, Pinela N, Arp DJ et al. (2010). Nitrosopumilus maritimus genome reveals unique mechanisms for nitrification and autotrophy in globally distributed marine crenarchaea. Proc Natl Acad Sci USA 107: 8818-8823.

Woodward EMS. (1994). Nanomolar Ammonia Concentrations in the Western Mediterranean Sea. 5th EROS 2000 Workshop: Hambourg, March 28-30. 
Wuchter C, Abbas B, Coolen MJ, Herfort L, van Bleijswijk J, Timmers $\mathrm{P}$ et al. (2006). Archaeal nitrification in the ocean. Proc Natl Acad Sci USA 103: 12317-12322.

Wuchter C, Schouten S, Boschker HT, Sinninghe Damste JS. (2003). Bicarbonate uptake by marine Crenarchaeota. FEMS Microbiol Lett 219: 203-207.

Yakimov MM, La Cono V, Denaro R. (2009). A first insight into the occurrence and expression of functional amo $A$ and accA genes of autotrophic and ammoniaoxidizing bathypelagic Crenarchaeota of Tyrrhenian Sea. Deep-Sea Res pII 56: 748-754.

Yakimov MM, La Cono V, Denaro R, D’Auria G, Decembrini F, Timmis KN et al. (2007). Primary producing prokaryotic communities of brine, interface and seawater above the halocline of deep anoxic lake L'Atalante, Eastern Mediterranean Sea. ISME J 1: 743-755.

Supplementary Information accompanies the paper on The ISME Journal website (http://www.nature.com/ismej) 